\title{
The clausal organization of Tuparí, an indigenous Brazilian language
}

\author{
ADAM ROTH SINGERMAN ${ }^{1,2^{*}}$ \\ ${ }^{1}$ University of Chicago, Chicago, USA \\ ${ }^{2}$ The Museu Paraense Emílio Goeldi, Belém, Brazil
}

Received: February 7,2020 • Accepted: November 15, 2020

(C 2020 Akadémiai Kiadó, Budapest

\begin{abstract}
This paper provides a detailed description and analysis of the clausal organization of Tuparí, a Tupían language that is spoken by approximately 350 people in the Brazilian state of Rondônia. The paper focuses on several interrelated issues that have broader comparative and typological importance, including $(a)$ the distribution of head-initial and head-final phrase structure, $(b)$ the diverse surface realizations of the Tense Phrase, and $(c)$ the distinction between true pronouns and pronoun-like agreement enclitics. Data are drawn from an in-progress corpus of native language texts, everyday conversations and elicited utterances. Differences between Tuparí and the other languages belonging to the Tupían family's Tuparían branch are highlighted at various points for comparative purposes.
\end{abstract}

\section{KEYWORDS}

Brazilian languages, syntax, headedness, agreement, tense

\section{INTRODUCTION}

This paper describes and analyzes the clausal organization of Tuparí, an indigenous Amazonian language spoken by approximately 350 people in the Brazilian state of Rondônia. We focus on several interrelated issues in Tuparí syntax that have broader comparative and typological importance, including $(a)$ the distribution of head-initial and head-final phrase structure; $(b)$ the

\footnotetext{
"Corresponding author. E-mail: adamsingerman@gmail.com
} 
diverse surface realizations of the Tense Phrase; and (c) the distinction between true pronouns and pronoun-like agreement enclitics.

We make four major claims in this paper concerning the organization of the Tupari clause. First, the language's functional categories obey the organizational scheme shown in Fig. 1. Immediately above the lexical verb we find the category of resultativity, realized via portmanteaux that also mark the subject's number and physical position. Habitual aspect is the next highest category, followed in turn by evidentiality, tense, and clause-typing - in that order. All functional categories below the Tense Phrase exhibit consistent head-final order. Yet there exists at the top of the clause a layer of unambiguous head-initiality, instantiated by enclitic particles located in second position.

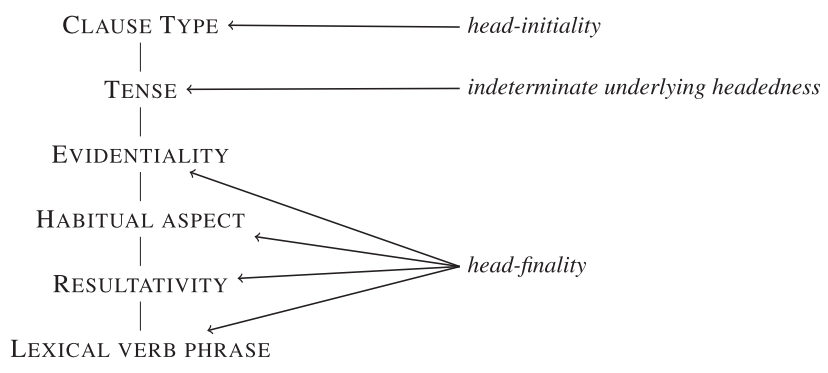

Fig. 1. The distribution of headedness in the Tuparí clause

The second claim advanced here is that the Tuparí Tense Phrase exhibits a combination of head-initial and head-final properties; in particular, T may be realized as an enclitic particle in second position or as a suffix that attaches at the right edge of the predicate. Both the second position tense particles and the predicate-final tense suffixes exhibit evidence of having been dislocated to their surface position via postsyntactic operations. As a result, the underlying headedness of the TP is best characterized as indeterminate.

Our third claim concerns the nature of those morphemes described as 'subject pronouns' or 'free pronouns' in prior literature on Tuparí and its closest relatives (Caspar and Rodrigues 1957; Alves 2004; Galucio and Nogueira 2011). We demonstrate that that literature conflated what are in fact two distinct sets of morphemes, easily confused with one other because of homophony in several person-and-number combinations. There exists a set of true pronouns, which may bear the same case morphology as other nominals. These true pronouns often serve discourse-related information structural roles; in particular, they may function as contrastive topics and as foci. The members of the other set of morphemes are restricted to finite clauses and are positionally parasitic on particular pieces of tense morphology. This set of properties makes sense only if the latter set of morphemes - here referred to as WEAK NOMINATIVE ENCLITICS - are not themselves true arguments of the verb but are instead a reflection of agreement between $\mathrm{T}$ and the subject.

Having shown that the weak nominative enclitics are parasitic on tense morphology, we arrive at our fourth claim: there exist at least two distinct null tense morphemes in Tuparí. One of these combines with verbal predicates that bear no overt tense or aspectual marking, while the other combines only with nominal predicates. Though both of these tense morphemes are null, they have sharply different effects on the placement of the weak nominative enclitics. We draw on data concerning the behavior of negated predicates - shown in Singerman (2018a) to behave 
like nouns rather than verbs - to further buttress the claim that Tuparí possesses two phonologically empty but syntactically active $\mathrm{T}$ heads.

The paper proceeds as follows. Section 2 reviews prior research into the morphosyntax of Tuparí. Section 3 establishes that the lower levels of the Tuparí clause are characterized by headfinal phrase structure, as is much of the nominal domain. Section 4 turns to the highest layer of the clause, instantiated by second position clause-typing particles, and argues that this layer is head-initial. Section 5 then addresses the mixed nature of the TP, which is shown to be of indeterminate underlying headedness. With this overall picture in place, Section 6 assesses the status and distribution of the weak nominative enclitics: T-parasitic morphemes that were misidentified as subject pronouns in prior literature. Using the close relationship between the weak nominative enclitics and $\mathrm{T}$ as a diagnostic tool, Section 7 examines those clauses which appear on the surface to be tenseless and argues that the language contains two null $\mathrm{T}$ heads. Section 8 concludes.

\section{BACKGROUND ON THE TUPARÍ LANGUAGE}

Descriptive material on the Tuparí language first became available in the 1950s thanks to the pioneering research of Franz Caspar (1956, 1957, 1975), a Swiss ethnographer who spent several months living among the Tuparí. A sketch of the language's phonology and morphology, based upon Caspar's fieldnotes, was subsequently elaborated by Aryon Dall'Igna Rodrigues (Caspar and Rodrigues 1957; for a recent Portuguese translation, see Caspar and Rodrigues 2017). Further descriptive work was carried out by Lucy Seki (2001), best known for extensive research into the Tupi-Guaraní language Kamaiurá (Seki 1990, 2000a, 2000b), and by Rodrigues's student Poliana Alves (1991, 2004).

The majority of the data presented in this paper were gathered between 2013 and 2018 over the course of approximately eleven months of on-site fieldwork on the Rio Branco Indigenous Reserve, located in the south of Rondônia. The remaining data have been gathered over WhatsApp, which has grown in popularity among Tuparí speakers now that internet access is available in many villages on the Rio Branco. In keeping with our broader commitment to use as much naturally occurring data as possible (Singerman 2018b, 9-12), we prioritize examples from texts and everyday casual conversations throughout this paper. Metadata indicate the provenance of the individual examples: utterances drawn from everyday conversation or elicitation are dated; textual excerpts are accompanied by the name of the author or narrator.

\section{HEAD-FINAL PHRASE STRUCTURE AT THE LOWER LEVELS OF THE CLAUSE AND IN THE NOMINAL DOMAIN}

This section establishes that the lower levels of the Tupari clause, together with noun phrases, are characterized by head-final rather than head-initial phrase structure.

Tuparí exhibits a host of head-final properties, just as many other Tupían languages of Rondônia do (see Moore 1984 on Gavião, Gabas Jr. 1999 on Karo, Galucio 2001, 2011, 2014 on Sakurabiát and Storto 1999, 2014, 2020 on Karitiana, among others). Within the nominal 
domain, adpositions follow the nouns they select for; case marking is suffixal; and the possessor must always precede the possessum. (1) through (3) highlight these properties. ${ }^{1}$

(1) Adpositions follow their complements
a. yam tere
yam tere
bench on.top.of
'on the bench'
$\begin{array}{ll}\text { b. yã } & \text { eanã } \\ \text { yã } & \text { eanã }\end{array}$
mother together.with
'together with mother'

(2) Case marking is suffixal

a. Tupari ema'erẽ

Tupari ema'ẽ-re

Tuparí language-oBL

'concerning the Tuparí language'

b. wema'em

w-ema'ẽ-m

1sG-language-INS

'with/in my language'

(3) Possessor precedes the possessum

a. esi

e-si

2sG-mother

'your mother'

b. esi memsit

e-si memsit

2sG-mother child.of.woman

'your mother's child'

\footnotetext{
${ }^{1}$ Abbreviations: $3 \mathrm{C}=$ the coreferential third person prefix te-, $\mathrm{ADV} \cdot \mathrm{FOC}=$ adverb focus, $\mathrm{AUx}=$ auxiliary, $\mathrm{CNDL}=$ counterfactual conditional, EVID $=$ evid, EXCL $=$ exclusive, $\mathrm{HZTL}=$ horizontal, $\mathrm{INCL}=$ inclusive, INS $=$ instrumentallative case, INTRANS $=$ intransitivizing prefix, $\mathrm{LOC}=$ locative case, $\mathrm{NEG}=$ negation, $\mathrm{NMZ}=$ nominalizer, $\mathrm{NUC}=$ nuclear case, $\mathrm{OBJ} . \mathrm{NMZ}=$ object nominalizer prefix, $\mathrm{OBL}=$ oblique case, $\mathrm{PAUC}=$ paucal, $\mathrm{PL}=$ plural, $\mathrm{PRIV}=$ privation, $\mathrm{PROG}=$ progressive, $\mathrm{RSLT}=$ resultative, $\mathrm{SG}=$ singular, $\mathrm{TH}=$ theme vowel, $\mathrm{UT}=$ Utterance Time, $\mathrm{vBZ}=$ verbalizer.

All examples are given in a four-line format. The first line gives the standard orthography used by the Tuparí schoolteachers on the Rio Branco Indigenous Territory; the second line gives a morphemic breakdown prior to the application of vowel deletion and consonant lenition processes. See Singerman (2016) and Singerman (2018b, appendix) for more information on these processes, which have the effect of obscuring certain morpheme boundaries on the surface.
} 
Whether Tuparí can be said to have true adjectives is controversial; Singerman (2018b, 87-92) argues that apparent adjectives are just a subclass of nouns. In terms of word order, however, adjective-like nouns must follow rather than precede the nouns which they modify. So 'adjectival' modification bucks the broader preference within the nominal domain for complementhead order.

(4) Adjectival modifiers follow the head NP
a. tarupa tàn
tarupa tàn
non.indigene tall
'the tall white person'
b. esi memsit pẽan
e-si memsit pẽan
2sG-mother child.of.woman first
'your mother's first child'

This deviation from complement-head order is crosslinguistically unsurprising, as adjectivenoun order does not exhibit clear correlations with other word order properties (see Dryer 1992; Hawkins 2004, 2014). Note that there is no relative clause modification within NPs, since all relative clauses in Tuparí are internally headed and are in fact clause-sized nominalizations (Singerman 2020).

Complement-head order obtains just as rigidly in the verbal domain as in the nominal one. Direct objects must precede the transitive verbs which select for them. OV order obtains with both pronominal objects (5a) and full NPs (5b).

(5) Direct objects occur immediately prior to the transitive verb
a. etoa
e-top-a
2SG-see-TH
'see you'
b. Arua 'ẽkaet toa
Arua 'ẽk-ap-et top-a
Aruá dance-NMZ-NUC see-TH
'see the dance of the Aruá'

Observe the layered head-finality in (5b): the lexical verb top 'see' takes as its direct object Arua ékaet 'dance of the Aruá', where Arua - another Tupían ethnic group of southern Rondônia - is the possessor of 'ékaet (a nominalization of the lexical verb 'êk 'dance').

The lexical VP must precede any and all positional, aspectual, or temporal auxiliaries; these are in turn rigidly ordered. In linear terms, the order which is invariant across all our data is (1) 
lexical VP, (2) positional auxiliary/AUX ${ }_{\mathrm{GO}}$, and finally (3) habitual auxiliary. ${ }^{2}$ Note that if the nonwitnessed evidential suffix -pnẽ/psira is present, it will attach to the rightmost auxiliary. This is shown by (6a) and (6b), two fully finite utterances that contain both tense and evidential morphology. In both examples the lexical VP precedes the lower auxiliary, tero'e ' $\mathrm{AUX}_{\mathrm{GO}} \mathrm{.SG}$ ' I oro' $^{\prime}$ ' $\mathrm{AUX}_{\mathrm{GO}}$.PAUC'; and this lower auxiliary in turn precedes the habitual auxiliary, 'eka / aka. It is the linearly rightmost - and structurally highest - auxiliary to which the evidential suffix -pnẽ / psira attaches. ${ }^{3}$

(6) Evidential suffix attaches to the rightmost / structurally highest auxiliary

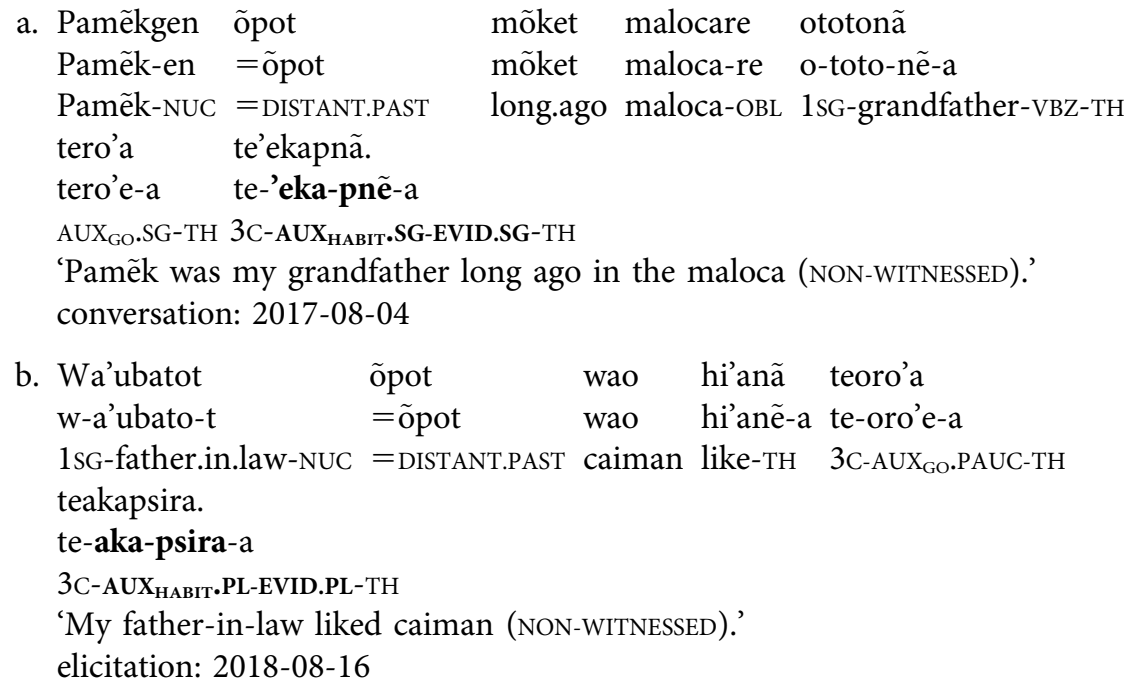

Data such as (6a) and (6b) point toward the tree in Fig. 2, which was first proposed in Singerman (2018b, ch. 5).

\footnotetext{
${ }^{2}$ The label $\mathrm{AUX}_{\mathrm{GO}}$ is used for a specific series of auxiliaries that bear a semi-transparent etymological relationship to the lexical verb 'go' (Singerman 2018b, 187-196). Distributionally, the members of the auxgo series are somewhat comparable to positional auxiliaries like $y \tilde{e}$ ' $\mathrm{AUX} \mathrm{HZTL}_{\mathrm{HL}}$.SG'. However, positional auxiliaries do not serve to create intermediate temporal gradations - one of the main purposes of the $\mathrm{AUX}_{\mathrm{GO}}$ series within the language's tense system. See Section 5 .

${ }^{3}$ There is no pronominal proclitic on the auxiliary tero' $a$ in (6a) because of a morphological haplology constraint that bars third person te- immediately prior to tet'e/tero'e 'AUX ${ }_{\mathrm{GO}} \cdot \mathrm{SG}^{\prime}$ (Singerman 2018b, 187-196). The same haplology constraint is at work in example (19e) (Section 5).

In traditional Tuparí speech in-laws are treated as paucals/plurals rather than as singulars. This is why wa'ubatot 'my father-in-law' triggers non-singular agreement in (6b): the auxiliary roots oro' ' $A U X_{\mathrm{GO}}$.PAUC' and aka 'AUX ${ }_{\mathrm{HABIT}}$.PL' and the plural evidential suffix -psira.
} 


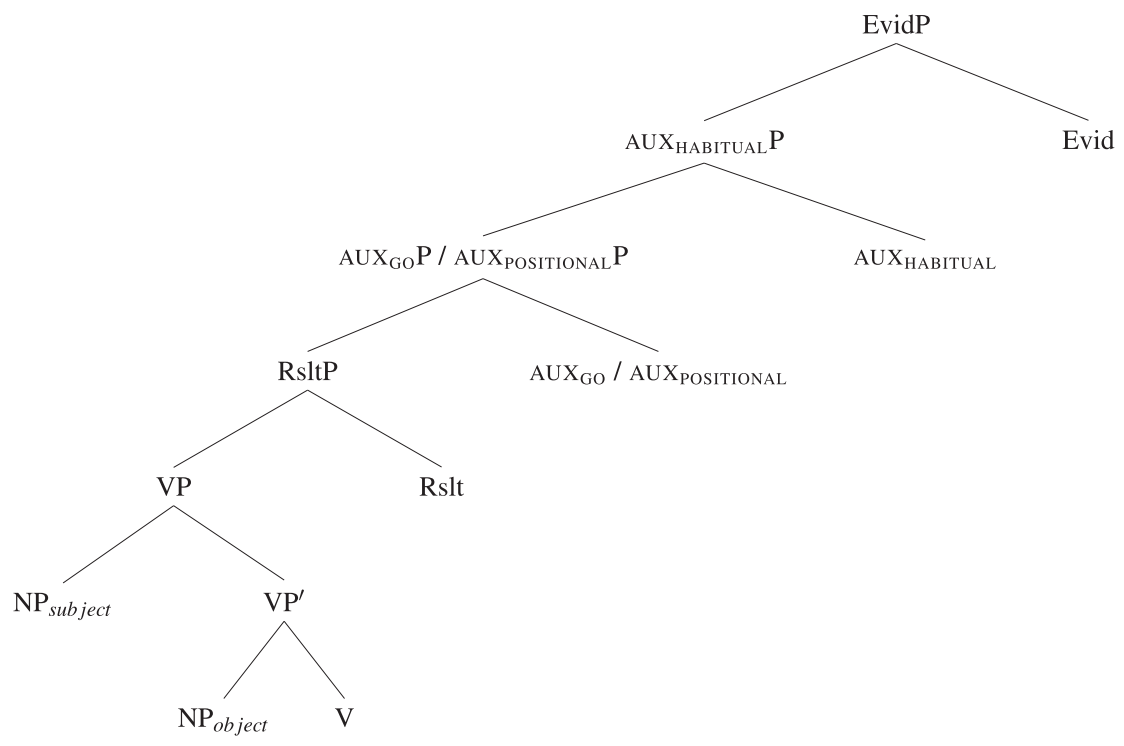

Fig. 2. The lower region of the Tupari clause is head-final

This tree includes - in a position immediately above the VP - the Resultative Phrase, realized by the suffix -psẽe/pnẽe/psira. More details about this suffix may be found in Singerman (2019); for now, we note that the head of this projection may duplicate the positional information provided by the lower of the two auxiliary heads. (7) provides an example of a headless relative clause where the Resultative head and both auxiliary heads are realized overtly. Examples like (7) demonstrate that while the resultative suffix and the lower auxiliary may expone the same number and positional information, they do head separate syntactic projections.

(7) Example where both the Resultative and AUX $\mathrm{POSITIONAL}_{\text {heads are realized }}$

\begin{tabular}{|c|c|c|}
\hline totot & tepsiksã & te'eka \\
\hline [ toto-t & 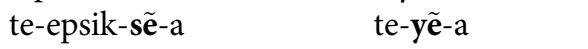 & te-'eka-a \\
\hline $\begin{array}{l}\text { [ grandpa-NUC } \\
\text { 'the place whe }\end{array}$ & $\begin{array}{l}\text { 3C-sit.down-RSLT }{ }_{\mathrm{HZTL}} . \mathrm{SG}-\mathrm{TH} 3 \mathrm{C}-\mathrm{AUX} \mathrm{HZTL}_{\mathrm{HZL}} \cdot \mathrm{SG}-\mathrm{TH} \\
\text { re grandpa regularly sits down' }\end{array}$ & 3C-AUX $\left.{ }_{\mathrm{HABIT}} \cdot \mathrm{SG}-\mathrm{TH}\right]$ \\
\hline
\end{tabular}

More examples of clausal nominalizations headed by hè are provided in the next section, which details the CP layer of the Tuparí clause.

\section{HEAD-INITIAL PHRASE STRUCTURE IN THE CP LAYER}

\subsection{The clause-typing particles}

Tuparí distinguishes different clause types using a set of 7 second position particles, listed in (8). Of these, $=n \tilde{e},=n \tilde{a} p e$ and ='aet were classified as members of a broader set of particles 
by Caspar and Rodrigues $(1957, \S 3.5)$, though their syntactic distribution was not explored in detail there.

(8) The clause-typing particles
a. $=n \tilde{e}$ 'YES/NO'
b. $=n \tilde{a} k o p$ 'MAYBE'
c. $=p a ' a / t a ' a$ 'ASSERTIVE'
d. =nãpe 'EMPHATIC'
e. =mãkẽrõ 'DONT.KNOW'
f. =mãkẽrõ 'CONFIRMATIVE'
g. ='aet 'UnFortunately.NOT' (i.e., 'it is a shame that $\neg p$ ')

We must distinguish between two homophonous clause-typing particles: mãkẽrõ 'DONT.KNOW' and mãkẽrõ 'CONFIRMATIVE'. They have distinct prosody (mãkẽrõ 'CONFIRMATIVE' is accompanied by a sharply rising intonation) and trigger different effects on the deictic orientation of the evidential suffix -pnẽ/psira (Singerman 2019, 411-428).

(9) shows the semantic effects that these clause-typing particles can have.

(9) Examples of clause-typing particles in existentials

a. Kafet nẽ te'a?

kafe- $\mathrm{t} \quad=$ nẽ te-'e- $\mathrm{a}$

coffee-NUC $=$ YES/NO 3C-AUX.SG-TH

'Is there coffee?'

common in everyday speech

b. Kafet nãkop te'a.

kafe-t =nãkop te-'e-a

coffee-NUC $=$ MAYBE 3C-AUX.SG-TH

'There might be coffee.' / 'I can't say for sure whether there's coffee.' conversation: 2015-12-22

c. Kafet pa'a te'a.

kafe-t = pa'a te-'e-a

coffee-NUC $=$ ASSERTIVE. ${ }^{\star}$ 3C-AUX.SG-TH

'There is indeed coffee.' / 'I assert that there is coffee.'

common in everyday speech

\footnotetext{
${ }^{4}$ The choice between the two allomorphs of the assertive particle is determined by the speaker's gender: = $p a$ 'a is used only by men and =ta'a, only by women. See Rose (2015) on gender indexicality in South American languages.
} 
An important fact about the clause-typing particles is that they only ever combine with fullyformed utterances. A clause that lacks an overt clause-typing particle is not ill-formed; it just instantiates a superficially unmarked sentence type. Hence the counterpart to (9a) through (9c) without an overt clause-typing particle is just a run-of-the-mill declarative, without any special emotive or emphatic content: Kafet te'a 'There is coffee'. That the clause-typing particles are added to otherwise fully-formed utterances supports an analysis on which these particles sit in a high position in the clausal spine, one above TP, EvidP, and the two auxiliary projections shown in Fig. 2. If this projection may host one and only one constituent in its specifier, as shown in Fig. 3, then we also explain why the clause-typing particles consistently surface in second position.

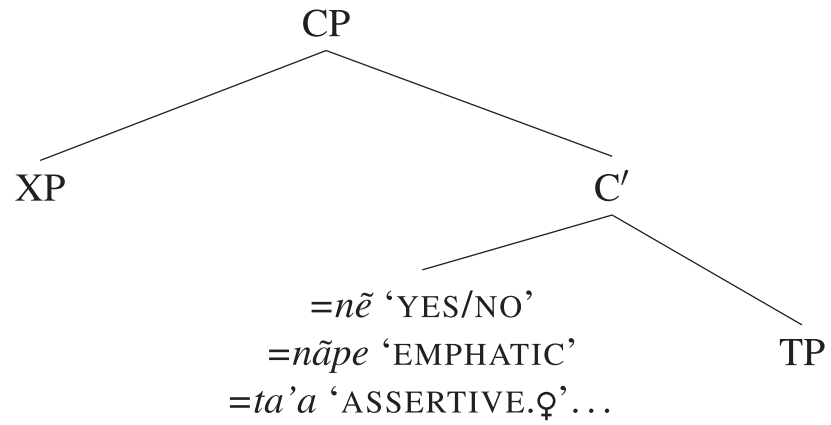

Fig. 3. The highest level of the Tuparí clause contains a head-initial CP

\subsection{What kind of constituents can precede the second position clause-typing particles?}

It is a well-established fact that morphemes may end up in second position by a variety of mechanisms. Second position effects - including Verb Second - bear the hallmarks of HEAD MOVEMENT in many languages, including German (den Besten 1983), Kashmiri (Bhatt 1999; Manetta 2011, 2020) and, within the Tupían family, Karitiana (Storto 1999, 2003, 2020). In other cases, however, phonological and/or prosodic mechanisms are needed to account for second position effects. This is the motivation behind Halpern's (1995) operation of Prosodic Inversion and behind Anderson's (2005) constraint-driven model of clitic placement. This subsection presents evidence that the placement of the clause-typing particles in second position is a syntactic phenomenon: the constituents that occur prior to the second position particle cluster in this language are not amenable to phonological or prosodic characterizations but must instead be defined in terms of syntactic integrity. To keep things easier on the reader we prioritize examples that contain $=n \tilde{e}$ 'YES/NO', one of the most common clause-typing particles. However, all of the clause-typing particles (listed in 8) exhibit identical behavior with regard to syntactic constituency.

The clause-initial constituent can be an NP subject, shown in (10) by the simplex uokat 'water' and by the slightly more complex Kopere ema'en 'language of the Djeoromitxí people'. Observe that all non-pronominal subjects are required to bear the nuclear case -et/ $e n / t / n$. 
(10) NP subjects serving as clause-initial constituents

a. Uokat nẽ poat pare poat'om nẽ?

$[\mathrm{NP}$ uoka-t $]=$ nẽ poat pare poat-'om $=$ nẽ $=\varnothing$

[NP water-NUC ] $=\mathrm{YES} / \mathrm{NO}$ good or good-NEG $=\mathrm{YES} / \mathrm{NO}=3$

'Is the water good, or is it not good?'

conversation: $2017-08-15$

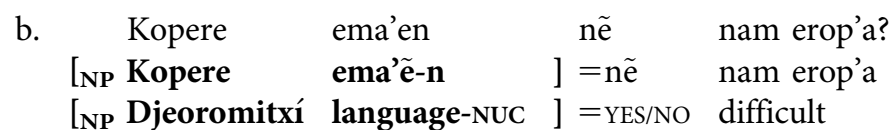

'Is the language of the Djeoromitxí people difficult?'

conversation: $2017-08-15$

Fully finite embedded clauses nominalized by hè can also serve as NP subjects (see Singerman 2020 for more on these clausal nominalizations, which are a diachronic innovation unique to Tuparí). In (11), the clausal nominalization immediately precedes the matrix clause-typing particle $=n \tilde{e}$ ' $\mathrm{YES} / \mathrm{NO}$ '.

(11) A finite embedded clause serving as the clause-initial subject

$\begin{array}{llll} & \text { Tarupat } & \text { teotsirat } & \text { hèt } \\ \text { [NP [s } & \text { tarupa-t } & \text { te-ot-sira-a-t } & \text { ] hè-t } \\ \text { [NP [s } & \text { non.indigene-NUC } & \text { 3C-go.PAUC-EVID.PL-TH-NEAR.PAST } & \text { ] NMZ-NUC ] } \\ \text { nẽ } & \text { eamigo? } & & \\ =\text { nẽ } & \text { e-amigo } & & \\ =\text { YES/NO } & \text { 2SG-friend } & & \end{array}$

'Are the white people who went (NON-WITNESSED) your friends?' conversation: 2016-01-25

The embedded clause in (11) is fully finite: tarupat teotsirat hèt 'the white people who went (NON-WITNESSED)' contains the plural evidential suffix - psira and the near past suffix - $t$. Note that this nominalization is interpreted as an INTERNALLY HEADED RELATIVE, one of the major functions of this language's finite embedded clauses (For more on IHRCs, see Cole 1987; Williamson 1987; Basilico 1996; Hiraiwa 2017; Ohara 2018; Hanink 2020).

The clause-initial constituent can also be a VP. Intransitive lexical verbs bear a pro-

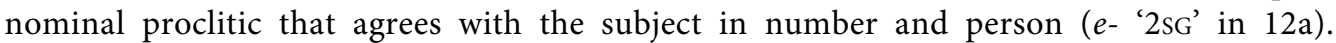
Transitive lexical verbs are immediately preceded by the direct object. ${ }^{5}$ This is true for

\footnotetext{
${ }^{5}$ A syntactic property shared by Tuparí and its sister languages (see Galucio 2001, 2002 on Sakurabiát; Nogueira 2011, 2019 on Wayoro; Aragon 2014 on Akuntsú) is that direct objects must be linearly adjacent to the transitive lexical verb. Due to this adjacency requirement - which we discuss in greater detail in separate work - transitive VPs front as a unit to the clause-initial syntactic position.

A reviewer asks about the fronting of indirect objects. Tuparí is a language with no ditransitive verbs: recipients, beneficiaries, and other prototypical indirect or secondary objects are encoded VP-externally as postpositional phrases. While a transitive verb and its direct object will front to clause-initial position as a single unit, those PPs must front separately from the VP itself.
} 
pronominal objects (third person $y$ - in 12b) and non-pronominal objects (ositot 'my foot' in 12c) alike.

(12) Verb phrases serving as clause-initial constituents

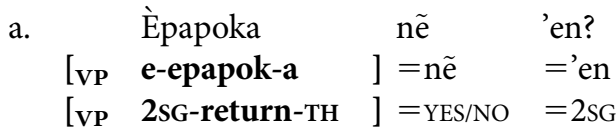

'Did you return?'

conversation: 2015-11-03

b. Yõ'era ne ko 'on?

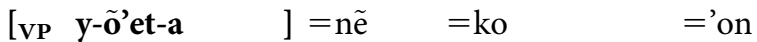

[vP 3-put.out-TH ] =YES/NO = POLITE.FUTURE $=1 \mathrm{SG}$

'Ought I to put it [a candle] out?'

conversation: 2018-08-08

c.

\begin{tabular}{|c|c|c|c|}
\hline Ositot & hawa & nẽ & ke \\
\hline & hawa-a & ]$=$ nẽ & $=\mathrm{ke}$ \\
\hline 1sG-foot-NUC & chop.up-TH & ] $=\mathrm{YES} / \mathrm{NO}$ & $=$ POLITE.FUTURE \\
\hline
\end{tabular}

'Do you want to chop up my foot?' / 'Careful, lest you should chop up my foot!' conversation: 2016-11-22

The direct object in a clause-initial verb phrase can also be a clausal nominalization headed by hè.

(13) Clause-initial VPs where the direct object is a finite embedded clause

a. Elizanin nemnan

hèt

peka

[vP [NP [s Elizani-n $\varnothing$-nẽ-mnẽ-a-n ] hè-t ] pek-a ]

[vP [NP [s Elizani-NUC 3-make-EVID.SG-TH-NEAR.PAST ] NMZ-NUC ] buy-TH ]

nẽ 'en?

$=$ nẽ $\quad=$ 'en

$=\mathrm{YES} / \mathrm{NO} \quad=2 \mathrm{SG}$

'Did you buy the thing that Elizane made (NON-WITNESSED)?' conversation: 2016-12-13

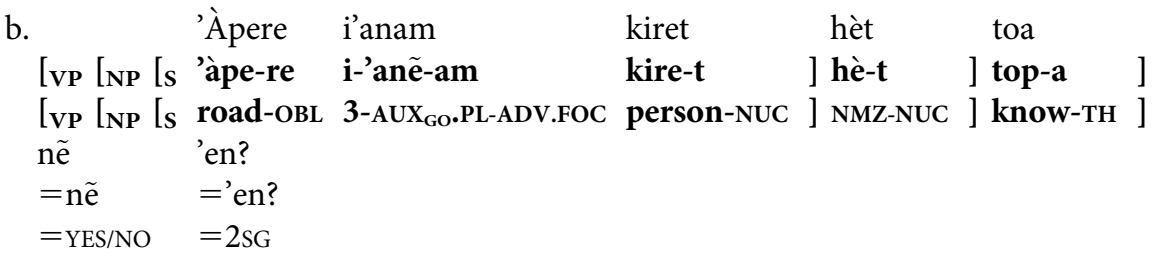

'Do you know the people who live alongside [=in villages alongside] the road?' conversation: $2015-10-28$ 
Like tarupat teotsirat hèt 'the white people who went (NON-WITNESSED)' in (11), the bolded constituents in (13) are interpreted as internally headed relatives: Elizanin nemnan hèt 'the thing that Elizane made (NON-WITNESSED)', where the internal head is a null pronominal object; 'àpère i'anam kiret hè 'the people who live alongside the road', where the internal head is the subject NP kiret 'the people'. In both of these examples, the transitive matrix verb together with the object serve as the clause-initial constituent. In this sense these data are fully parallel to (12b) and $(12 c)$, despite the intuitive difference in weight: whereas the object in (12b) is a mere pronominal proclitic and that in (12c), a possessed noun, in (13a) and (13b) the direct objects are fully finite clausal nominalizations.

Other kinds of constituents, such as adverbials, can also serve as the clause-initial constituent. Here, too, we observe the same range of possibilities already seen in (10) through (13): the clause-initial adverbial may be very small (just monomorphemic) or very large (say, an entire finite embedded clause).

(14) Examples of adverbials serving as clause-initial constituents
a. Eret nẽ ke 'en etet cidadzim? [AdvP eret $]=n \tilde{e} \quad=k e \quad$ ='en e-tet cidadzi-m
[AdvP tomorrow ] $=$ YES/NO = POLITE.FUTURE $=2$ SG 2sG-go.sG city-INS
'Are you going to go to the city tomorrow?'
conversation: 2016-11-22
b.
2sG-all-forget-again

$\begin{array}{llllll} & \text { Eapsitkòmkara } & \text { e'a } & \text { nẽ } & \text { ke } & \text { 'en } \\ \text { [AdvP } & \text { e-apsitkòmkat-a } & \text { e-'a } & \text { ] =nẽ } & =\text { ke } & =\text { ='en } \\ \text { [AdvP } & \text { 2sG-grow.sad-TH } & \text { 2sG-if.sG } & \text { ] = YES/NO } & =\text { POLITE.FUTURE } & =2 S G \\ \text { èrote'apsitwaronã? } & & & & \\ \text { e-erote-apsitwat-ronã } & & & & \end{array}$

'If you grow sad will you again forget all [that you have learned]?' / 'Be careful, lest you should grow sad and again forget all [that you have learned]!' conversation: 2018-08-07

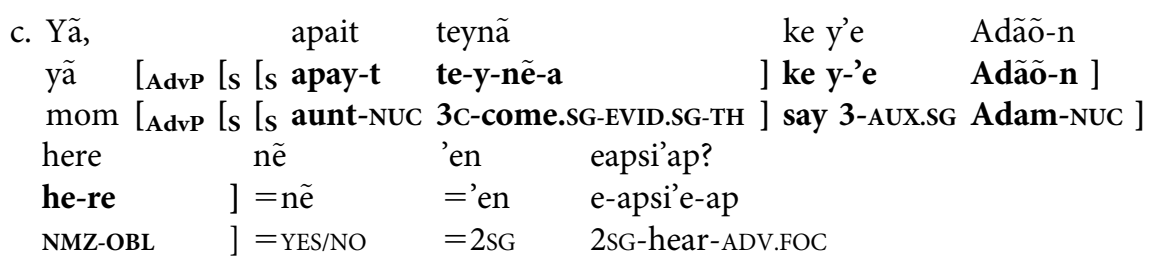

'Mom, did you hear that Adam said that auntie came (NON-WITNESSED)?' conversation: 2017-08-03

In (14a) the clause-initial adverbial - eret 'tomorrow' - is monomorphemic. In (14b) the clauseinitial adverbial is structurally more complex, containing a lexical verb - apsitkòmkat 'grow sad' - as well as the subordinating morpheme (')a 'if, when'. (Both the lexical verb and the subordinator are preceded by the second person singular prefix e-.) And in (14c) the clause-initial 
constituent is a clausal nominalization, headed by hè, that itself contains a direct quotation: apait teynã ke y'e Adãõn 'Adam said that auntie came (NON-WITNESSED)'.

We must emphasize that the second position facts shown above are consistent across speakers, independent of gender, knowledge of Portuguese, or other sociolinguistic factors. Speakers never interrupt clause-initial constituents with second position particles; they always respect those constituents' internal integrity. In short, what matters for the placement of the clause-typing particles is syntactic constituency. We therefore maintain that the tree given in Fig. 3 - where a single constitutent may occupy Spec,CP, thus yielding the placement of the clause-typing particles in second position - is the right representation for the highest layer of the Tuparí clause.

\subsection{The clause-typing particles as $\mathrm{C}$ heads}

The projection headed by the clause-typing particles is given as $\mathrm{C}$ in Fig. 3. Motivation for this label comes from the fact that the clause-typing particles are sensitive to whether or not the clause-initial constituent is $[+w h]$, just like complementizers in better studied languages (such as English if, whether and that). Only =nãpe 'EMPHATIC' and = mãkẽrõ 'DONT.KNOW' may occur with $[+w h]$ clause-initial constituents.

(15) Sensitivity of clause-typing particles to [ $\pm w h]$ status of the clause-initial constituent
a. Katkaere nãpe
omemsĩremsĩren tèsapwa
katkaere = nãpe
o-memsirremsin-en te-s-a-pwa
when =EMPHATIC
1SG-grandchild-NUC 3C-come.SG-TH-NEAR.FUTURE 3-AUX.SG
'When on earth is my grandchild going to come here?'
conversation: 2016-11-11
b. Katkaere mãkẽrõ omemsiremsirren tèsapwa
katkaere =mãkẽrõ o-memsiremsin-en te-s-a-pwa
When = DONT.KNOW 1sG-grandchild-NUC 3C-come.SG-TH-NEAR.FUTURE
y'e.
y-'e
3-AUX.SG

y'e?

y-'e

'I don't know when my grandchild is going to come here.' elicitation: 2017-08-06

\footnotetext{
${ }^{6}$ The nominalizer hè bears the oblique case ending -ere in (14c) because the matrix verb apsi'e 'hear, listen, understand' selects for oblique-marked arguments. This is illustrated by (i), where the oblique argument is a normal NP - not a finite embedded clause:
}

(i) Ema'ẽ poarere wapsi'a o'e.

ema'ẽ poat-ere w-apsi'e-a o-'e

speech good-oBL 1SG-hear-TH 1SG-AUX.SG

'I have heard good news.'

conversation: 2017-08-05

See Singerman (2020) for many more examples of clausal nominalizations that carry case morphology on hè. 
c. Katkaere *ta'a / ${ }^{*}$ ñ / ${ }^{*}$ 'aet / ${ }^{*}$ nãkop omemsirremsirren tèsapwa y'e elicitation: 2017-08-06

Analyzing the clause-typing particles as heading C, as we have done here, is further supported by the fact that all $w h$-words in Tuparí must occur clause-initially; wh-in-situ is categorically unattested. (See Brandon and Seki 1981, 1984 for early discussion of wh-movement in Tupían languages.) The $w h$-word will immediately precede an overt clause-typing particle in the linear string. ${ }^{7}$

A wh-word must always occur clause-initially in Tuparí

a. Apo nãpe

Adãõ yam weret

ma'aren?

apo $=$ nãpe $=\varnothing$ Adãõ yam w-et-et

ma'ẽ-a-n-en

who $=$ EMPHATIC $=3$ Adam to 1sG-name-NUC tell-TH-NEAR.PAST-NUC

'Who on earth told my name to Adam?!'

conversation: 2016-11-16

b. Katkaere mãkẽrõ ko

katkaere $=$ mãkẽrõ $\quad=$ ko

'on aodeyam oterap.

when = DONT.KNOW = POLITE.FUTURE $=1 \mathrm{sG}$ village-INS 1SG-go.SG-ADV.FOC

'I don't know when I will go to the village.'

conversation: 2016-11-11

c. Pare mãkẽrõ õpot

pare $=$ mãkẽró $=\tilde{o p o t}$

'en ewaet

ãpeap.

where $=$ DONT.KNOW $=$ DISTANT.PAST $=2$ SG 2 SG-hammock-NUC hang-ADV.FOC

'I don't know where you hung your hammock, years back.'

conversation: 2017-08-09

When a wh-word is the complement of a postposition or the possessor of another noun, the entire phrase will pied-pipe.

$$
\begin{aligned}
& \text { Apo nẽkat kire mãkẽrõ nerõ tero'at. } \\
& \text { [ apo nẽkat kire } \quad]=\text { mãkẽrõ } \quad=\varnothing \text { nerõ tero'e-a-t } \\
& \text { [NP who kind person }]=\text { DONT.KNOW }=3 \text { PROG } \mathrm{AUX}_{\mathrm{GO}} \cdot \mathrm{SG}-\mathrm{TH}-\mathrm{NUC}
\end{aligned}
$$

'I don't know what kind of person that is.'

conversation: 2016-11-29

\footnotetext{
${ }^{7}$ A reviewer asks whether Tuparí permits multiple wh-questions and, if so, whether all of the $w h$-constituents must front. I cannot answer this question at present, but hope to gather data on the behavior of multiple wh-questions during the next round of field research.
} 
The sensitivity of the various clause-typing particles to the $[ \pm w h]$ status of the clause-initial constituent can be interpreted as a reflex of the wh-criterion (Rizzi 1996). On this analysis the particles are simply complementizers, each specified as compatible or incompatible with a $[+w h] \mathrm{XP}$ in their specifier. More specifically, $=$ mãkẽró 'DONT.KNOw' requires a $[+w h]$ constituent to sit in Spec,CP; =nãpe 'EMPHATIC' accepts a constituent that is $[+w h]$, though it will also accept a $[-w h]$ constituent; and the remaining particles are all incompatible with $[+w h]$ clause-initial constituents.

\subsection{Summary}

The data discussed in this section have demonstrated that it is syntactic constituency that determines the placement of the clause-typing particles in second position. Analytically we have implemented this finding by positing a head-initial CP at the top of the Tuparí clause, as in Fig. 3; this projection will host a single XP in its specifier, giving rise to the clause-typing particles' placement in second position. So while the lower levels of the Tuparí clause show clear head-finality, at the top we find unambiguously head-initial phrase structure. In the next section we turn to the Tense Phrase, which is located between these two zones of headedness and which shares properties with both of them.

\section{MIXED HEADEDNESS IN THE TENSE PHRASE}

This section asks about the headedness of the Tupari TP, which is sandwiched between the CP and the EvidP. Does the TP pattern like the projections located beneath it - the EvidP, the two AuxPs, and the VP - all of which are head-final? Or does the Tuparí TP pattern like the projection located above it - the $\mathrm{CP}$ - which is head-initial? The former possibility is illustrated in Fig. 4; the latter, in Fig. 5.

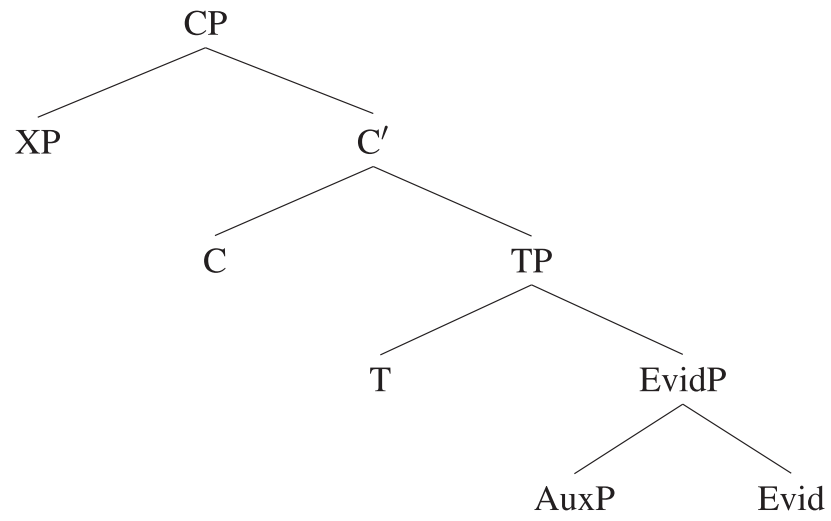

Fig. 4. If the TP is head-initial, like the CP above it 


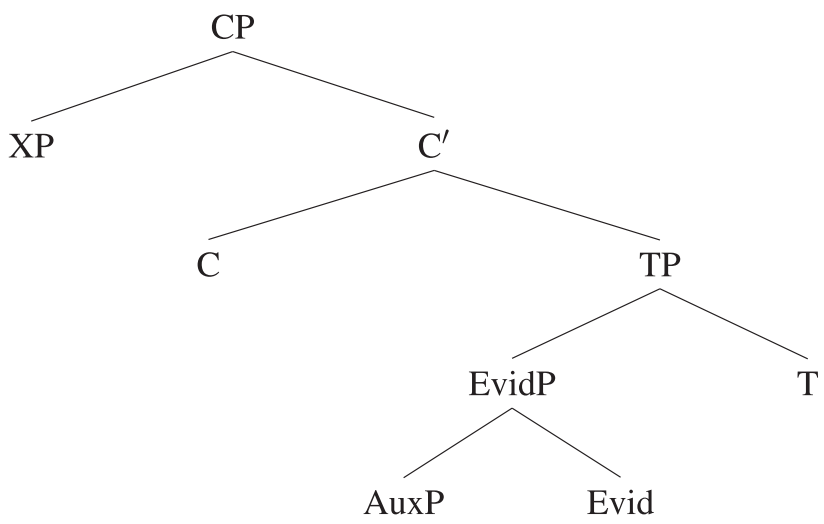

Fig. 5. If the TP is head-final, like the EvidP below it

There are two main purposes to this section. First, we demonstrate that, at least on the surface, both kinds of headedness are attested within the Tuparí TP: some realizations of T behave head-initially, whereas others behave head-finally. Second, we argue that the UNDERLYING headedness of the TP is obscured by dislocation operations: head-initial T morphemes (realized as second position enclitic particles) and head-final $\mathrm{T}$ morphemes (realized as predicate-final suffixes) both undergo some form of movement to reach their surface position, such that neither set provides an unfiltered view of the TP's headedness.

\subsection{An overview of tense marking in Tuparí}

The full set of tense marking in Tuparí is heterogenous and consists of three mutually exclusive sets of morphemes: $(a)$ predicate-final suffixes, $(b)$ enclitic particles located in second position, and $(c)$ auxiliaries that follow the lexical VP. Despite this heterogeneity, all three sets of morphemes behave comparably in discourse and serve the same general semantic function - namely, to anchor the event time with respect to the Utterance Time (UT). For reasons of space this paper focuses on the predicate-final suffixes and the second position particles. For more information on the post-VP auxiliaries that mark tense and aspect, the reader is referred to Singerman (2018b, ch. four).

The paradigm in (18) gives an illustration of the predicate-final suffixes and second position particles, which paradigmatically oppose one another. In each of the four utterances, the relevant tense morphology is highlighted, as is the second position clause-typing particle $=$ mã $\tilde{k} \tilde{e} \tilde{o}$ 'DONT.KNOW'.

(18) Past tense paradigm

a. Pare mãkẽrõ ewaet 'en.

pare =mãkẽrõ e-wap-et ãpe-a-t ='en

where = DONT.KNOW 2SG-hammock-NUC hang-TH-NEAR.PAST $=2 \mathrm{SG}$

'I don't know where you hung your hammock [BETWEEN TWO DAYS BEFORE UT AND A FEW MONTHS BEFORE UT].'

elicitation: 2018-08-16 
$\begin{array}{llllll}\text { b. Pare } & \text { mãkẽrõ } & \text { ewaet } & \text { ãpea } & \text { etero'at } & \text { 'en. } \\ \text { pare } & =\text { mãkẽrõ } & \text { e-wap-et } & \text { ãpe-a } & \text { e-tero'e-a-t } & \text { ='en }\end{array}$ where = DONT.KNOW 2sG-hammock-NUC hang-TH 2SG-AUX GO $_{\text {oSG-TH-NEAR.PAST }}=2 \mathrm{SG}$ 'I don't know where you hung your hammock [THREE + MONTHS BEFORE UT].' elicitation: 2018-08-16

c. Pare mãkẽrõ onpot en ewaet ãpeap. pare =mãkẽrõ =õpot ='en e-wap-et ape-ap where $=$ DONT.KNOW $=$ DISTANT.PAST $=2 \mathrm{SG}$ 2sG-hammock-NUC hang-ADV.FOC 'I don't know where you hung your hammock [A FEW YEARS BEFORE UT].' conversation: 2017-08-09

d. Pare mãkẽrõ onpot 'en ewaet ãpea pare =mãkẽró =õpot ='en e-wap-et ape-a where = DONT.KNOW = DISTANT.PAST $=2 \mathrm{SG}$ 2SG-hammock-NUC hang-TH etet'e. e-tet'e

$2 \mathrm{SG}-\mathrm{AUX} \mathrm{X}_{\mathrm{GO}} . \mathrm{SG}$

'I don't know where you hung your hammock [MANY YEARS BEFORE UT].' elicitation: 2018-08-16

We have highlighted the clause-typing particles in these five examples to emphasize that whereas the tense particles will occur in the second position particle cluster - immediately following the clause-typing particle - the predicate-final tense suffixes may be realized far from second position. As shown in (18b), the predicate-final suffix will attach to the auxiliary when one is present; in the absence of an auxiliary, as in (18a), the suffix attaches to the lexical verb itself.

The second position tense particles and predicate-final tense suffixes must be analyzed as constituting a single grammatical class. They all carry out the same semantic function: they anchor the event time with respect to the utterance time. As indicated by the translations in (18), the near past suffix $-t / n$, the distant past particle $=\tilde{o}$ oot and the ancient past particle $=k u t$ divide the before-now timeline into carefully delineated intervals: $-t / n$ is used for events that took place at least two days before UT through several months into the past; $=\tilde{o p o t}$, for events from approximately two years before UT to the speaker's early childhood; and $=k u t$, for events that took place prior to or at the speaker's birth. The predicate-final durative suffix - pbi'a/mbi'a, meanwhile, conflates tense, aspect and evidentiality: it is used for non-future habitual actions that the speaker has witnessed firsthand. Speakers are very strict about the meaning of each of these morphemes. Misusing them gives rise to inaccurate temporal interpretations (and aspectual/evidential ones, in the case of durative -pbi'a/ $\left.m b i^{\prime} a\right)$; these erroneous uses are in turn subject to correction by native speakers. And as demonstrated by the textual data in Singerman (2018b, 298-303), all of this tense morphology behaves comparably in running discourse.

A further reason to analyze the second position tense particles and the predicate-final tense suffixes as instantiating the same overarching grammatical category is that members of both sets of morphemes can combine with the $\mathrm{AUX}_{\mathrm{GO}}$ auxiliary series to introduce intermediate temporal 
gradations. The near past suffix - $t$ in (18a) marks the hammock-hanging event as having taken place between two days and several months before UT; but the combination of $-t / n$ 'NEAR.PAST' with the $\mathrm{AUX}_{\mathrm{GO}}$ in $(18 \mathrm{~b})$ yields a more removed temporal interpretation. In a comparable fashion, the second position tense particle $=\tilde{o}$ pot in (18c) marks the hammock-hanging event as having taken some two years prior to UT; and the addition of the $\mathrm{AUX}_{\mathrm{GO}}$ in (18d) pushes the temporal interpretation back even farther.

The difference between the pair in (18a) and (18b), or between the pair in (18c) and (18d), is not akin to that between English went and had gone. English-style pairs of past and past perfect indicate the relationship that two different past tense events have to one another (see Klein 1992). In Tuparí, however, the combination of a predicate-final suffix or second position particle with a member of the $\mathrm{AUX}_{\mathrm{GO}}$ series is part of the language's nuanced tense system: these combinations are used to introduce intermediate temporal gradations, all of which are anchored to the UT. Consider (19). These five lines are excerpted from a text that relates a series of events which took place more than just a few months ago (and therefore too far back for the narrrator to use the near past suffix $-t / n$ ) but less than two years ago (and therefore too recent for him to use the distant past second position particle $=\tilde{o} p o t)$. Each finite clause in this excerpt contains both near past $-t$ and a member of the $\mathrm{AUX}_{\mathrm{GO}}$ series: paucal oro'e in (19a), singular tero'e in (19b) through $(19 \mathrm{e})$.

(19) Textual example of $-t / n$ 'NEAR.PAST' combining with auxiliaries from the AUX $\mathrm{GO}_{\mathrm{GO}}$ series

a. Here otewãrã oteoro'at 'ote.

here ote-wan-a ote-oro'e-a-t ='ote

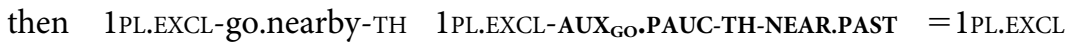

'Then we-EXCL went a short distance.'

b. Here okoa otero'at 'on,

here o-kop-a o-tero'e-a-t ='on

then 1SG-descend-TH 1SG-AUX ${ }_{\mathrm{GO}}$.SG-TH-NEAR.PAST $=1 \mathrm{SG}$

'Then I got down [from the tree],'

c. here owãrã otero'at 'on iyam.

here o-wan-a o-tero'e-a-t ='on iyam

then 1SG-go.nearby-TH 1SG-AUX GO $_{\text {SG }}$-TH-NEAR.PAST $=1 \mathrm{SG}$ to.him

'and I went a short distance to him.'

d. Here sesua otero'at 'on,

here s-esu-a o-tero'e-a-t ='on

then 3 -call-TH $1 \mathrm{sG}-\mathrm{AUX}_{\mathrm{GO}}$.SG-TH-NEAR.PAST $=1 \mathrm{SG}$

'Then I called out to him,'

e. here òyãora tero'are.

here o-õyaot-a tero'e-a-t =e

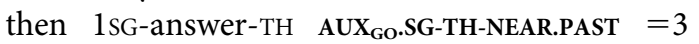

'and he answered me.'

text: Nilson Tupari, narrator 
Just like the predicate-final suffix $-t / n$ 'NEAR.PAST', the second position particle $=\tilde{o} p o t$ 'DISTANT.PAST' will combine with the $\mathrm{AUX}_{\mathrm{GO}}$ series to produce more nuanced temporal gradations. Example (20a) is how an elderly woman described being breastfed by her grandmother, her mother having passed away soon after her birth. The speaker of this example is around eighty years old, and consultants confirm that both the distant past particle $=\tilde{o}$ pot and the auxiliary tet'e are obligatory here. Using $=\tilde{o}$ pot without tet'e, as in (20b), would work only if someone much younger - say, a young child were to relate an event that had taken place just a few years before UT. ${ }^{8}$

$\mathrm{AUX}_{\mathrm{GO}}$ introduces intermediate temporal gradations with $=\tilde{o}$ pot 'DISTANT.PAST'
a. Opapa
kẽrẽ
opot
'on okemkà
o-papa
ke(m)-re
$=\tilde{\text { oppot }}$
='on
o-kemko-a
1SG-grandmother
breast-OBL
$=$ DISTANT.PAST $=1 \mathrm{SG}$
1SG-nurse-TH
otet'epnẽ.
o-tet'e-pnẽ
1SG-AUX ${ }_{\text {GO.SG-EVID.SG }}$
'I nursed at my grandmother's breast (NON-WITNESSED) [MANY YEARS BEFORE UT].' text: Marilza Kabatoá Tupari, narrator
b. Opapa kẽrẽ õpot on okemkopnam.
o-papa $\quad \mathrm{ke}(\mathrm{m})$-re =õpot ='on o-kemko-pnẽ-am
1SG-grandmother breast-OBL = DISTANT.PAST =1SG 1SG-nurse-EVID.SG-ADV.FOC
'I nursed at my grandmother's breast (NON-WITNESSED) [JUST A FEW YEARS BEFORE UT].'

elicitation: 2016-01-23

In sum, there are multiple reasons to analyze the predicate-final tense suffixes and second position tense particles as belonging to a single grammatical class. First, with the exception of the particle $=k o / k e$ 'POLITE.FUTURE', all of these morphemes divide up the prior-to-UT timeline in comparable fashion. Second, they all may combine with the same auxiliary series to produce intermediate temporal gradations. Third, these morphemes behave identically in actual discourse; running texts see the right tense morpheme repeated in every clause. This was shown for the near past suffix $-t / n$ in (19): each finite clause in that textual excerpt contains both the near pst suffix and a member of the $\mathrm{AUX}_{\mathrm{GO}}$ series. Singerman (2018b, 298-303) provides comparable textual evidence for distant past $=\tilde{o}$ pot, ancient past $=k u t$, and durative $-p b i$ ' $a / m b i$ ' $a$. As these morphemes all share comparable semantics, enjoy similar distribution in discourse, and are mutually exclusive, they must be analyzed as realizing the same overarching grammatical category.

\footnotetext{
${ }^{8}$ As shown in Section 3, the non-witnessed evidential suffix -prẽ/psira must attach to the highest verbal head in the clause. This is why in (20a) - pne 'EVID.SG' attaches to the auxiliary tet' ' 'AUX ${ }_{\mathrm{GO}}$.SG', which follows the lexical verb kemko 'nurse, breastfeed', but why in (20b) - which has no auxiliary - -pne 'EvID.SG' instead attaches to the lexical verb itself. This suffix must be used here since an infant cannot volitionally witness her own breastfeeding. Example (29b), in Section 6, provides another case of evidential -pnẽ/psira combining with a first person subject. See Singerman (2019, appendix) for discussion of the different pragmatic inferences that arise in such cases.
} 


\subsection{What is the underlying headedness of the Tupari Tense Phrase?}

Having argued that the predicate-final suffixes $-t / n$ 'NEAR.PAST' and $-p b i$ 'a/mbi'a 'DURATIVE' and the second position particles $=k o / k e$ 'POLITE.FUTURE', $=\tilde{o}$ pot 'DISTANT.PAST' and $=k u t$ 'ANCIENT.PAST' all instantiate T, we must ask about the headedness of the Tense Phrase. To consider the different analytical possibilities, consider the four-member past tense paradigm given in (18). In (18b), the near past suffix - $t$ attaches to the auxiliary root tero'e 'AUX $\mathrm{GO}_{\mathrm{GO}} \mathrm{SG}$ ', which itself follows the VP ewaet apea. This VP is head-final, too, with the direct object ewaet 'your hammock' preceding rather than following the transitive verb ãpea 'hang up'. In this sense $\mathrm{T}$ in (18b) is head-final, just like the other projections below it: the VP and the AuxP. In (18c) and (18d), on the other hand, the distant past particle $=\tilde{o}$ pot sits in second position, immediately after the clause-typing particle =mãkẽró 'DONT.KNOW'. There is no evidence in (18c) or (18d) of T behaving comparably to the head-final VP or head-final AuxP; rather, it behaves like the C projection, which we argued in Section 4 to be head-initial.

One could imagine three possible lines of analysis. T, like C, could be underlyingly headinitial, such that the surface position of the predicate-final tense suffixes is the result of some dislocation operation. On this analysis, it is the second position particles that reflect the underlying headedness of the TP. Alternatively, T could be head-final, like the EvidP and other lower projections, such that the appearance of the tense particles in second position results from dislocation. On this analysis, the predicate-final suffixes, not the second position particles, are what reflect the TP's underlying headedness. Finally, it is possible that neither the second position tense enclitics nor the predicate-final tense suffixes reflect the underlying headedness of the Tense Phrase. We will argue for this third analysis: both sets of morphemes undergo some form of dislocation to reach their surface position, such that neither the predicate-final suffixes nor the second position particles provide an unfiltered view of the underlying headedness of the TP.

5.2.1. The second position particles undergo dislocation to their surface position. Recall that the second position tense particles always occur immediately after a clause-typing particle (if one is present). Inverting the linear order of the two particles is completely unattested. Several examples containing both an overt clause-typing particle and an overt tense particle were already given in Sections 4.2 and 5.1 (21) provides three more.

(21) The clause-typing particle immediately precedes the tense particle in second position

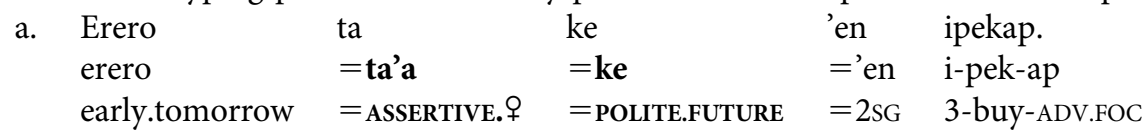

'Please buy it early tomorrow morning.'

conversation: 2018-08-31

b. En nãkop õpot 'en Marli wãkiret kat.

en =nãkop =õpot ='en Marli wãkit-et ko-a-t

$2 \mathrm{SG}=$ MAYBE $=$ DISTANT.PAST $=2 \mathrm{SG}$ Marli pet-NUC eat-TH-NUC

'Perhaps it was you who long ago ate Marli's pet.'

conversation: 2018-08-07 


$\begin{array}{lllll}\text { c. Pare mãkẽrõ } & \text { kut } & \text { yan } & \text { osinã } & \text { tet'e. } \\ \text { pare = mãkẽró } & =\text { kut } & \text { yã-n } & \text { o-sinẽ-a } & \text { tet'e } \\ \text { where = DONT.KNOw } & =\text { ANCIENT.PAST } & \text { mother-NUC } & \text { 1sG-give.birth-TH } & \text { AUX }{ }_{\mathrm{GO}} \text {.SG } \\ \text { 'I do not know where my ormmother } & \text { gave birth to me.' } \\ \text { conversation: } 2017-08-30 & \end{array}$

That the tense particle immediately follows the clause-typing particle in the second position cluster can be accounted for by T-to-C Head Movement (for discussion of Head Movement see Travis 1984; Matushansky 2006; Harley 2013; Zeller 2013; McCloskey 2017, among many others). T and C will thus form a single complex head which follows the clause-initial constituent. Positing T-toC Head Movement in this circumstance successfully captures the fact that in utterances that contain both a clause-typing particle and a second position tense enclitic, they are always adjacent; to our knowledge, no other material is ever capable of surfacing between them.

However, if the tense particles arrive in second position via T-to-C Head Movement, then an underlyingly head-final TP and an underlyingly head-initial TP will both serve equally well: the original headedness of the TP will be hidden by the application of Head Movement. Put slightly differently: if T-to-C Head Movement always applies to ensure that the tense particles surface in second position, then these particles will tell us nothing about the TP's underlying headedness. This is illustrated by Figs 6 and $7 .^{9}$

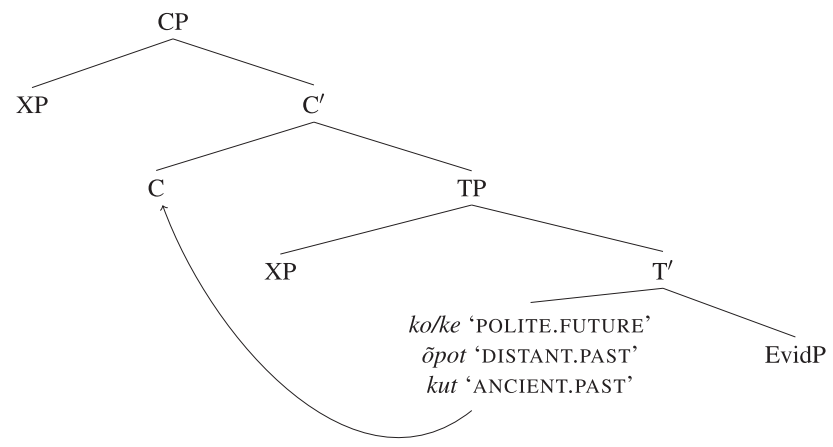

Fig. 6. Tense undergoes Head Movement to $C$ from head-initial TP

\footnotetext{
${ }^{9}$ Singerman (2018b, ch. five) proposed an alternative analysis that does not invoke T-to-C Head Movement. Rather, the TP was analyzed as underlyingly head-initial and lacking a specifier; the second position tense particles underwent no dislocation but instead surfaced naturally following the higher $\mathrm{C}$ head, thanks to the lack of an intervening specifier. That analysis assumed the existence of a null $\mathrm{C}$ head in declaratives. (Editor Éva Dékány points out that this assumption is unproblematic: declarative force must be encoded in declarative clauses.) However, the analysis further assumed that the specifier-less TP would never occur without a higher C layer, since that would yield (contrary to fact) clause-initial attestations of the second position tense particles. For these reasons we prefer the analysis proposed here, according to which the TP does have a specifier and T-to-C Head Raising applies.
} 


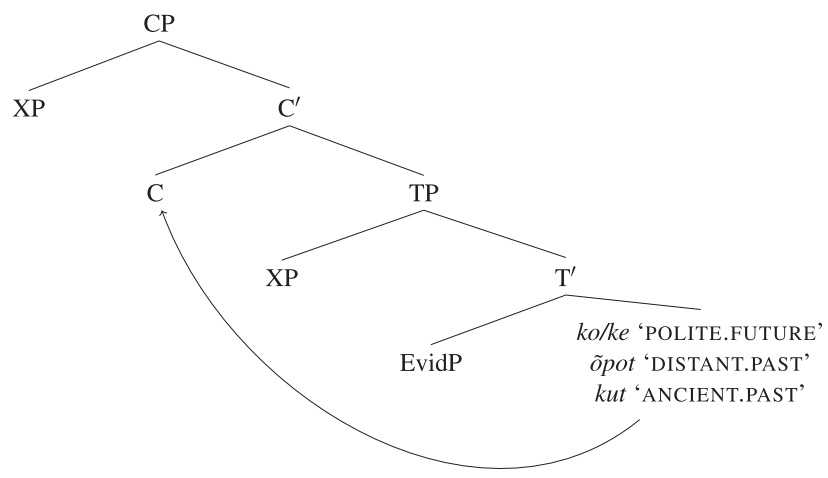

Fig. 7. Tense undergoes Head Movement to $C$ from head-final TP

A comparable situation obtains in the Germanic languages, which are standardly analyzed as displaying Head Movement from $\mathrm{T}$ to $\mathrm{C}$; it is this operation that accounts for the Verb Second (V2) pattern. But the headedness of the $\mathrm{T}$ and $\mathrm{V}$ projections varies among the Germanic languages: for example, these projections are standardly analyzed as head-final in German but as head-initial in English (See den Besten 1983; Haider and Prinzhorn 1986; Vikner 1995 as well as various contributions to Wolfe and Woods 2020.). Thanks to the fact that the $\mathrm{C}$ projection is consistently head-initial across Germanic, T-to-C Head Movement will yield V2 surface order (or, in the absence of an initial constituent, verb-initial order) regardless of the underlyingly headedness of the TP or VP. In much the same way, the obligatory Head Movement of the second position particles $=k o / k e$ 'POLITE.FUTURE', $=\tilde{o} p o t$ 'DISTANT.PAST' and $=k u t$ 'ANCIENT.PAST' from $\mathrm{T}$ to $\mathrm{C}$ means that these particles are uninformative as to the underlying headedness of the Tuparí TP.

A reviewer points out that recent scholarship has problematized the traditional conception of Head Movement: what was previously viewed as a unitary process may in fact consist of several distinct operations, each with its own set of properties. In particular, Harizanov and Gribanova (2019) propose to bifurcate classic Head Movement into (a) Internal Merge, which applies to full words and belongs to the core syntactic component, and (b) Head Raising, which is a postsyntactic operation involved in word-building (=morphological) processes. This bifurcation allows Harizanov and Gribanova to explain those cases of Head Movement that have been argued to have interpretive consequences (see for instance Keine and Bhatt 2016 on the German construction known as the LONG PASSIVE). On Harizanov and Gribanova's typology, such cases are the product of Internal Merge; that is, they must apply within the narrow syntactic component. Cases which do not affect interpretation, on the other hand, may result either from Internal Merge or from the postsyntactic operation of Head Raising.

The reviewer asks where the Tuparí facts fit into the refined typology of Harizanov and Gribanova. Do Figs 6 and 7 illustrate an application of Internal Merge, which by definition must take place within the narrow syntax, or an application of postsyntactic Head Raising? As a preliminary answer to this question, observe that the semantic contribution of the different tense morphemes is unconnected to whether they are realized as a predicate-final suffix (near past $-t$ / $n$, in examples $18 \mathrm{a}$ and $18 \mathrm{~b}$ ) or as a second position particle (distant past $=\tilde{o}$ pot, in $18 \mathrm{c}$ and $18 \mathrm{~d}$ ). 
There is zero correlation in Tuparí between where tense morphology is ultimately realized in the clause and what kind of semantic contribution that morphology provides. This lack of semantic consequence is compatible in principle with either the Internal Merge or Head Raising operations, since on Harizanov and Gribanova's theory Internal Merge may yield semantic effects but need not do so. More decisive evidence comes from the fact that the second position particles $=k o / k e$ 'POLITE.FUTURE', =o opot 'DISTANT.PAST' and $=k u t$ 'ANCIENT.PAST' do not constitute fullyformed words in their own right; rather, they are bound, destressed morphemes that must encliticize onto preceding material. (That material will be a clause-typing particle, if one is present, though the clause-typing particle in turn must encliticize onto the clause-initial XP. If there is no overt clause-typing particle, then the tense particle will lean onto the clause-initial XP directly.) For Harizanov and Gribanova, Internal Merge applies to fully-formed words while Head Raising may be driven by purely morphological considerations. The operation that best accounts for the realization of certain tense morphology as second position enclitic particles in Tuparí would thus be Head Raising (with right adjunction to ensure that the tense particle follows rather than precedes the clause-typing particle).

The next subsection discusses what the suffixes $-t / n$ 'NEAR.PAST' and $-p b i$ 'a/mbi'a 'DURATIVE' can reveal about the underlying headedness of the Tense Phrase. These suffixes arrive in their surface position, at the right edge of the predicate, via a Lowering operation. As a result, they are also uninformative with regards to whether the Tuparí TP should be analyzed as underlyingly head-initial or underlyingly head-final.

5.2.2. The predicate-final suffixes also undergo dislocation to their surface position. The surface position of the predicate-final suffixes does not tell us anything more about the underlying headedness of the TP than the second position particles do. This is because of the nature of predicate fronting in Tuparí. When a lexical verb cooccurs with one or more auxiliaries, only the VP headed by the lexical verb may occur to the left of a second position clausetyping particle. The auxiliary or auxiliaries will surface to the right of the clause-typing particle. As a result of the fact that the tense suffix $-t / n$ 'NEAR.PAST' always attaches to the highest verbal head, in examples like (22a) the clause-typing particle will linearly separate the lexical VP from the auxiliary that bears the tense suffix.

(22) Placement of clause-typing particles in clauses with auxiliaries

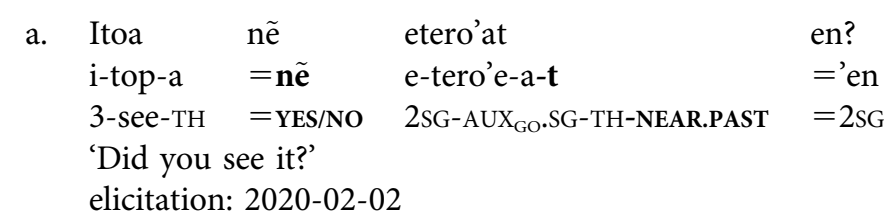
b. *Itoa etero'at nẽ 'en?
i-top-a e-tero'e-a-t =nẽ ='en
3-see-TH $2 \mathrm{SG}^{-A U X_{\mathrm{GO}} . \mathrm{SG}-\mathrm{TH}-\mathrm{NEAR} . P A S T}=$ YES/NO $=2 \mathrm{SG}$
(intended to mean the same as 22a)
elicitation: 2020-02-02


The crucial observation is that in (22a) only the lexical VP itoa occurs prior to the clause-typing particle $=n \tilde{e}$ 'YES/NO'. The auxiliary, meanwhile, surfaces to the right of the clause-typing particle; and it is to the auxiliary that the near past suffix attaches. As (22b) demonstrates, placing both the lexical VP and the tense-marked auxiliary prior to $=n \tilde{e}$ 'YES/NO' results in ungrammaticality. The contrast between (22a) and (22b) shows that a full TP cannot front to the clause-initial position, which we identified in Section 4 as Spec,CP. But now consider the examples in (23), where - due to the lack of an auxiliary - the tense suffix surfaces on the lexical verb itself. Here, the lexical VP occurs to the left of the second position clause-typing particle $=n \tilde{e}$ 'YES/NO'.

Fronted VPs that themselves carry tense morphology
a. E'ẽkapbi'a
e-'ẽk-a-pbi'a
nẽ 'en mõket?
2SG-dance-TH-DURATIVE $=$ YES/NO $=2$ SG long.ago
'Did you used to dance?'
elicitation: 2018-08-23
$\begin{array}{llll}\text { b. Epuop'orat } & \text { nẽ } & \text { 'en haytokia? } \\ \text { e-puop'ot-a-t } & =\mathbf{n e} & =\text { 'en haytokia }\end{array}$
2 sG-learn-TH-NEAR.PAST $=$ YES/NO $=2 \mathrm{SG}$ a.lot
Did you learn a lot?
elicitation: 2018-09-01

Example (22a) would appear to contradict the two utterances given in (23): according to the former the fronted constituent is smaller than TP, since $-t / n$ 'NEAR.PAST' surfaces on the auxiliary, which remains to the right of the clause-typing particle in the linear string; but in the latter, the fronted VP itself bears the tense suffix, thereby suggesting that a constituent larger than just the VP itself has fronted to Spec,CP.

To resolve this contradition we propose that utterances such as (28a) and (23b) feature Lowering (Harley and Noyer 1999; Embick and Noyer 2001; Harizanov and Gribanova 2019) from $\mathrm{T}$ to the next highest syntactic head in the clausal spine. This head may be an evidential suffix, the structurally highest auxiliary, or the the lexical verb itself. In this last case a lexical verb that bears tense morphology can front to the clause-initial position (=Spec,CP), as in (28a) and (23b).

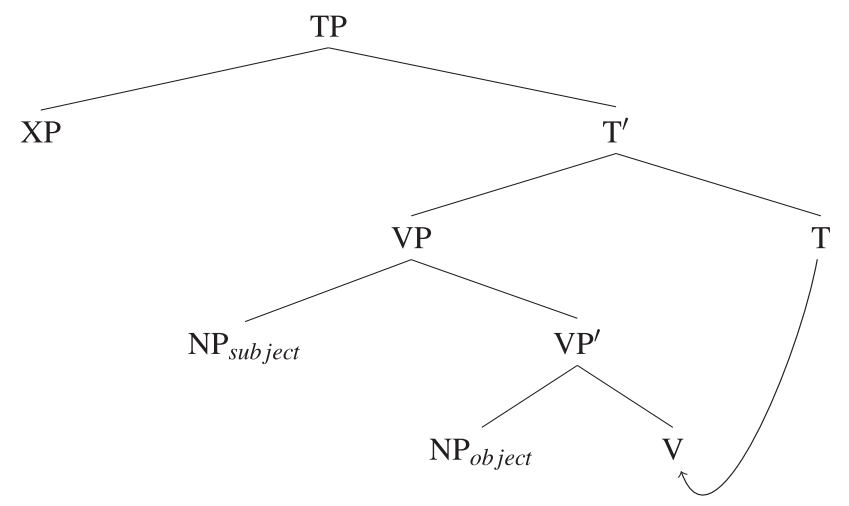

Fig. 8. Tense suffix undergoes postsyntactic Lowering to $V$ from head-final $T$ 


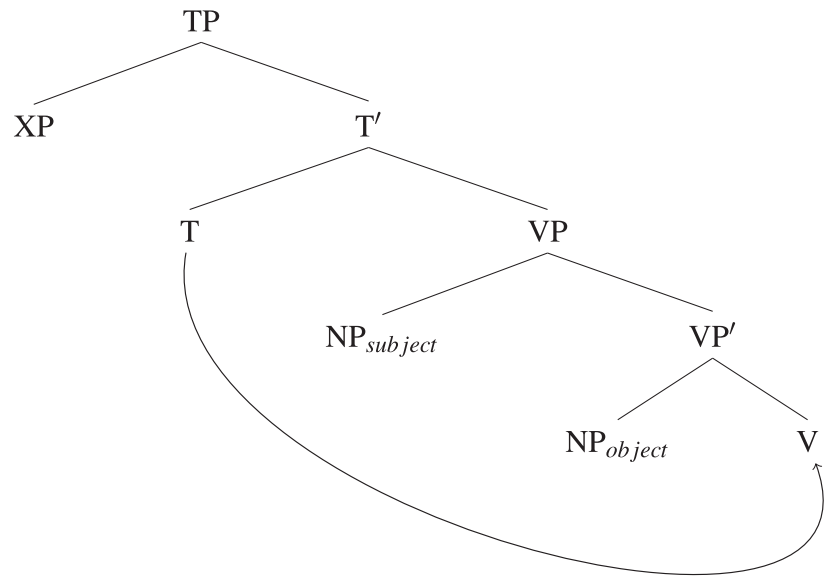

Fig. 9. Tense suffix undergoes postsyntactic Lowering to $V$ from head-initial $T$

But just as Figs 6 and 7 demonstrated for T-to-C Head Raising, the underlying headedness of the TP is irrelevant once Lowering applies. A head-final TP (as in Fig. 8) or a head-initial one (Fig. 9) will serve equally well, since both satisfy the head-to-head locality condition that is hypothesized to characterize postsyntactic head-displacement operations. In sum, the predicatefinal tense suffixes do not help to disambiguate the basic headedness of the TP any more than the second position tense particles do. Rather, both sets of tense morphemes are dislocated to their surface position.

Here we find an interesting parallel to the facts surrounding the second position particles $=k o / k e$ 'POLITE.FUTURE', $=\tilde{o} p o t$ 'DISTANT.PAST' and $=k u t$ 'ANCIENT.PAST', which were discussed in the prior subsection. That subsection argued that if we assume the bifurcation of Head Movement proposed by Harizanov and Gribanova (2019), then the second position particles must reach their surface position via an application of the postsyntactic operation of Head Raising rather than the narrowly syntactic operation of Internal Merge. As evidence in favor of a postsyntactic rather than narrowly syntactic account for the second position particles' behavior, we observed that the particles themselves do not qualify as independent words but are instead phonologically dependent enclitics. The same logic applies to the predicate-final suffixes, too: these morphemes are not independent words but rather bound affixes that must attach to a verbal stem. ${ }^{10}$ We thus arrive at a picture of Tuparí tense morphology where one of two different postsyntactic operations will apply, depending on the specific piece of morphology that is present. In the case of the second position particles, that operation will be Head Raising from $\mathrm{T}$ to $\mathrm{C}$. In the case of the predicate-final suffixes, the operation will be Head Lowering from $\mathrm{T}$ to

\footnotetext{
${ }^{10}$ As evidence of these suffixes' dependent status, they are subject to the process of progressive nasal spreading discussed in Singerman (2016). It is this process which turns the near past suffix into $-n$, and the durative suffix into - $m b i$ ' $a$, following nasal vowels.
} 
the head of the next-highest projection in the clause (which may be the Evidential Phrase, an Auxiliary Phrase, or the VP itself). ${ }^{11}$

5.2.3. A note on the headedness of the Evidential Phrase. Taking the reasoning given in Sections 5.2.1 and 5.2.2 to its logical end, one could argue that the Evidential Phrase is of indeterminate underlying headedness, just as the Tense Phrase is. This is because the evidential suffix -pné/psira, just like the predicate-final tense suffixes - $t / n$ 'NEAR.PAST' and -pbi'a/mbi'a 'DURATIVE', will surface on a fronted VP in the absence of an auxiliary. The pair of utterances in (24) illustrates. In (24a), where there is no auxiliary, the singular evidential suffix - pne surfaces on the lexical verb itself; here the VP serves as the clause-initial constituent. In (24b), however, it is the auxiliary tet'e 'AUX ${ }_{\mathrm{GO}} \mathrm{SG}^{\text {' }}$ ' that bears -pnẽ ; the lexical VP in clause-initial position does not bear evidential morphology.

\section{Predicate fronting with evidential morphology}

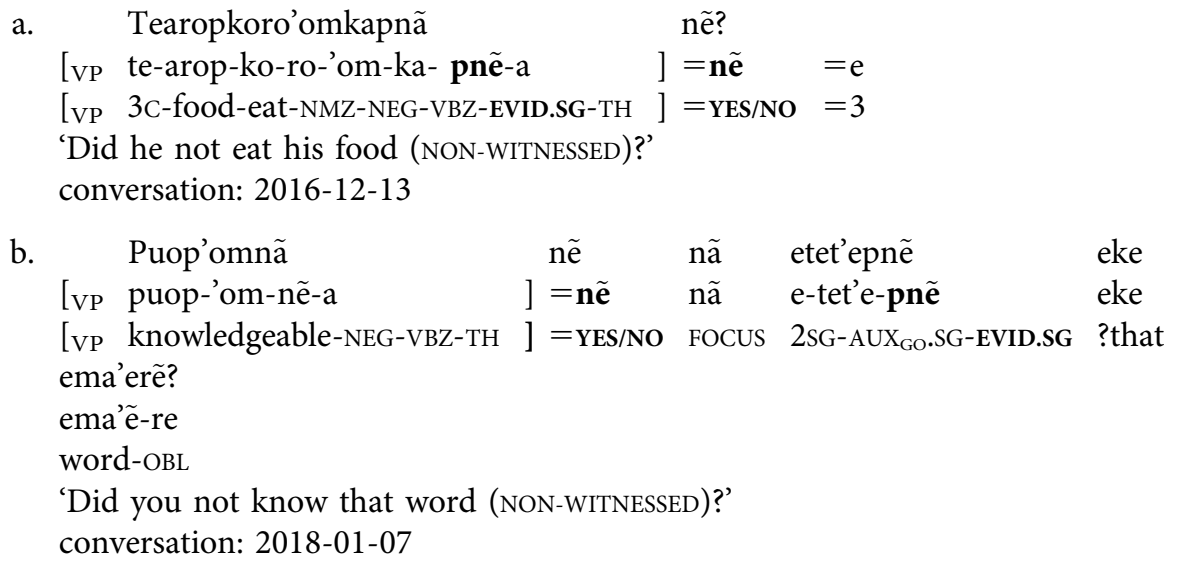

These data suggest that the evidential suffix - pnẽ/psira must also undergo Head Lowering to the next-highest verbal head (which may or may not be an auxiliary), just as the predicate-final tense suffixes do (This application of Lowering would then feed the fronting of the VP to Spec, $\mathrm{CP}$ and, as a result, would give rise to the same apparent paradox discussed in footnote 11.) But if the evidential suffix undergoes the same kind of Head Lowering that the predicate-

\footnotetext{
${ }^{11}$ A reviewer points out that examples such as the two given in (23) appear to involve an application of Head Lowering, which is hypothesized to apply postsyntactically, followed by an application of VP-fronting - a narrowly syntactic operation. This is a contradiction for any model that assumes a one-way feeding relationship from the core or narrow syntax to the post-syntax. As pointed out by the reviewer, this contradiction is problematic given that movement of constituents into Spec,CP in Tuparí can have interpretive consequences: as shown by the examples in Section 4.3, wh-fronting is an obligatory operation in Tuparí. And although our work on information structure in this language is still in progress, the available evidence shows that all exhaustive or identificational foci (to borrow the terminology of É. Kiss 1998) must also front to Spec,CP. At the same time, this contradiction would not be the first time a postsyntactic operation has been analyzed as feeding a narrowly syntactic one; Martinović (2019), for example, proposes this exact circumstance for Wolof. To provide a Martinović-style analysis for the Tuparí facts would require discussion of the nature of phasehood in this language, but I lack data at present that bear on this issue. The question of how to resolve (a) data such as the two utterances in (23) and (b) the traditional assumption that postsyntactic operations may not feed narrowly syntactic ones must remain unanswered for now, though investigating this issue should be a priority for future research into Tuparí syntax.
} 
final tense suffixes do, then the EvidP could be underlyingly head-final or head-initial, too. On this analysis the region of unambiguous head-finality in the Tupari clause (see Fig. 2) would include AUX $_{\text {HABITUAL }} \mathrm{P}$, the projection immediately beneath EvidP, but would exclude the EvidP itself.

Note, however, that the evidential suffix -prẽ/psira differs from the heterogenous category of tense in that it lacks any head-initial realizations comparable to the second position particles $=k o / k e$ 'POLITE.FUTURE', = o pot 'DISTANT.PAST' and $=k$ ut 'ANCIENT.PAST'. Rather, it always surfaces as a suffix; and this suffix must attach to the highest verbal head in the predicate, whether this is the lexical verb itself (example 24a) or an auxiliary (24b; see also $6 \mathrm{~b}$ and 20a). For these reasons this paper takes the EvidP to be underlyingly head-final, as was first argued for in Singerman (2018b) and further assumed in Singerman (2019), though this assumption is not crucial.

\subsection{Summary}

This section has examined the headedness of the Tuparí Tense Phrase, which sits above a zone of head-finality and beneath a zone of head-initiality. Recent research into disharmonic syntax has argued that head-initiality works 'top down' and head-finality 'bottom up' within Extended Projections (in the sense of Grimshaw 2000, 2005). If only one head-initial phrase occurs within an Extended Projection, it will be the highest one; if only one head-final phrase occurs within an Extended Projection, it will be the lowest. This observation has grown out of a range of scholarship on Final-over-Final Condition/Constraint, first proposed in Holmberg (2000) and later relativized to Extended Projections by Biberauer et al. (2014) (see also Sheehan et al. 2017). Main clauses in Tuparí conform to FOFC in that clearly head-final phrase structure is found at the bottom of the clause whereas unambiguous head-initiality occurs only at the top. ${ }^{12}$ In between these two domains we encounter the murky, indeterminate TP, indicated in Fig 10 with dotted lines.

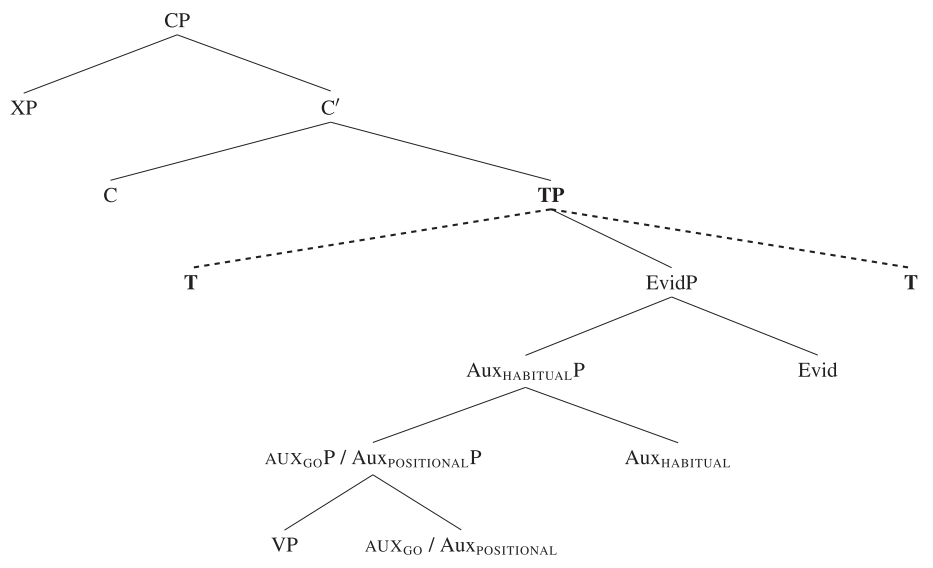

Fig. 10. The Tuparí Tense Phrase is of indeterminate underlying headedness

\footnotetext{
${ }^{12}$ Whether embedded clauses in Tuparí also comply with FOFC is a different, and more difficult, question. See Singerman (2020) for discussion.
} 
This kind of clausal organization is likely widespread within the Tupían family, as various Tupían languages have head-final VPs but exhibit V2/second position effects alongside obligatory wh-movement to the left periphery. See, among others, Brandon and Seki $(1981,1984)$ on Kamaiurá, Moore (1984) on Gavião, Gabas Jr. (1999) on Karo, and Storto $(1999,2014)$ on Karitiana.

\section{USING THE TENSE PHRASE TO DISENTANGLE TWO DIFFERENT SETS OF MORPHEMES: THE STRONG PRONOUNS AND THE WEAK NOMINATIVE ENCLITICS}

Having arrived at an understanding of the distribution of head-initial and head-final phrase structure in the Tuparí clause, we are now in the position to make sense of the the morphemes called 'subject pronouns' in previous descriptions of Tuparí (Alves 2004, §4.3.1.6) and as 'free pronouns' in recent comparative work on the Tuparían branch of Tupían (Galucio and Nogueira 2011). This section demonstrates that there are in fact two different sets of morphemes at work here. One set consists of true pronominal roots; these roots pattern morphosyntactically like normal nominals. The other set consists of phonologically weak elements that are parasitic on tense marking in a manner suggestive of agreement morphology.

The label adopted here for this latter set of morphemes - WEAK NOMINATIVE ENCLITICS - is intended to capture three important generalizations. First, the weak nominative enclitics function only in the nominative grammatical role ( $\mathrm{S}$ and $\mathrm{A}$ to the exclusion of O/P, in terms of Dixon 1979 and Comrie 1981). Second, the weak nominative enclitics must always occur with a host on their left; they are barred from occurring in clause-initial position. Third, the weak nominative enclitics are parasitic on the position of tense morphology within the clause and are licensed only when a specific kind of tense marking is present. Once these generalizations are established, it becomes possible to distinguish between two sets of morphemes that were conflated in prior scholarship.

\subsection{The distribution of the weak nominative enclitics}

Table 1 shows the seven weak nominative enclitics (see Singerman 2018b, 29-42 for discussion of their morphophonology). These enclitics are subject to the following requirement: they must occur immediately after the tense morpheme, whether this is a second position particle or predicate-final suffix. The crucial factor that determines the availability and placement of the weak nominative enclitics is the kind of tense marking present. (It is for this reason that we can only describe these enclitics now, following Section 5's discussion of the headedness of the TP.)

Table 1. The set of weak nominative enclitics

\begin{tabular}{|c|c|c|c|}
\hline & SINGULAR & DUAL & PLURAL \\
\hline $1 \mathrm{INCL}$ & \multirow[t]{2}{*}{ ='on } & $=$ 'okit & ='okitwat \\
\hline 1EXCL & & \multicolumn{2}{|c|}{$=$ 'ote } \\
\hline 2 & $=$ 'en & \multicolumn{2}{|c|}{$=w a t$} \\
\hline 3 & \multicolumn{3}{|c|}{$=e$ (but $\varnothing$ in certain contexts) } \\
\hline
\end{tabular}


In utterances where $\mathrm{T}$ is realized as a second position particle, the weak nominative enclitic must immediately follow it. The minimal pair in (25), offered back-to-back in conversation by an elderly speaker, illustrates.

Weak nominative enclitics will follow tense particles in the second position cluster

$\begin{array}{lllll}\text { a. Wepsika } & \text { ko } & \text { 'on } & \text { omemsĩremsin } & \text { yare. } \\ \text { w-epsik-a } & =\text { ko } & =\text { 'on } & \text { o-memsiremsin } & \text { yare } \\ \text { 1 SG-sit.down-TH } & =\text { POLITE.FUTURE } & =\mathbf{1 S G} & \text { 1SG-grandchild } & \text { next.to }\end{array}$

Let me sit down next to my grandchild.

conversation: 2016-12-12

b. Omemsiremsin yare ko 'on wepsikap.

o-memsiremsin yare =ko ='on w-epsik-ap

1sG-grandchild next.to $=$ POLITE.FUTURE $=1 \mathrm{sg}$ 1sG-sit.down-ADV.FOC

Let me sit down next to my grandchild.

conversation: 2016-12-12

In (25a) the clause-initial constituent is the verb wepsika; the postpositional phrase omemsiremsin yare occurs to the right of the second position cluster. In (25b) that postpositional phrase now serves as the clause-initial constituent, while the VP wepsikap (bearing special adverbial focus morphology) follows the second position cluster. Yet in both examples ='on ' $1 \mathrm{SG}$ ' occurs to the immediate right of $=k o$ 'POLITE.FUTURE'. The syntactic category of the clause-initial constituent and the linear location of the lexical verb are irrelevant for the placement of the weak nominative enclitic; the only important factor is the presence of the particle $=k o$ 'POLITE.FUTURE'. As this particle occurs in second position, first person singular $=$ 'on must also do so.

Separating the weak nominative enclitic from the tense particle leads to ungrammaticality.

(26) Weak nominative enclitics cannot be separated from second position tense particles

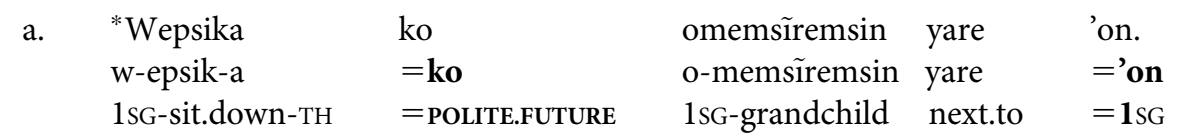

(intended to mean the same as $25 \mathrm{a}$ and $25 \mathrm{~b}$ )

elicitation: 2018-08-19

b. *Omemsiremsin yare ko wepsikap 'on.

o-memsĩremsin yare =ko w-epsik-ap ='on

1sG-grandchild next.to $=$ POLITE.FUTURE 1SG-sit.down-ADV.FOC $=\mathbf{1 s G}$

(intended to mean the same as $25 \mathrm{a}$ and $25 \mathrm{~b}$ )

elicitation: 2018-08-19

This pair of ungrammatical utterances demonstrates that no material may intervene between a second position tense particle like $=k o$ 'POLITE.FUTURE' and a weak nominative enclitic. 
In the case of the predicate-final tense suffixes $-t / n$ 'NEAR.PAST' and $-p b i$ 'a/mbi'a 'DURATIVE', the weak nominative enclitic will surface immediately after the suffix. The clause-typing particles and weak nominative enclitics are highlighted in (27) so as to emphasize that while the clausetyping particles invariably occur in second position (just like the particles $=k o / k e$ 'POLITE.FUTURE', $=\tilde{o}$ pot 'DISTANT.PAST' and $=k u t$ 'ANCIENT.PAST'), the weak nominative enclitics do not.

Weak nominative enclitics will follow the predicate-final tense suffixes

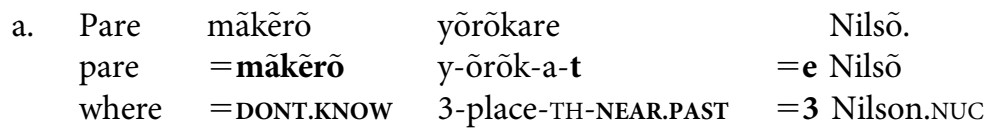

'I don't know where Nilson placed it.'

conversation: 2017-08-14

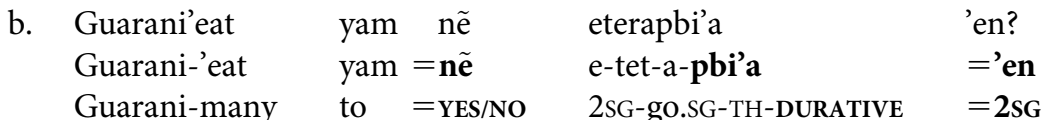

'Do you ever go to the Guarani? / Did you used to go to the Guarani?' conversation: 2016-12-13

In both of these examples an overt clause-typing particle sits in second position, thereby demarcating the right boundary of the clause-initial constituent (pare 'where', Guarani'eat yam 'to the Guarani'). But the weak nominative enclitics do not appear in second position; they instead follow the tense suffix (-t/n 'NEAR.PAST', - $p b i$ 'a/mbi'a 'DURATIVE'). So there exists no direct connection between the weak nominative enclitics and second position. Rather, the position of the weak nominative enclitics depends on that of tense - a grammatical category that is itself split in realization between predicate-final suffixes and second position particles. Whenever a weak nominative enclitic occurs in second position, it is because tense morphology is there, too. (In Section 7 we will use this generalization to argue that the position of weak nominative enclitics in superficially tenseless clauses provides evidence for the presence of a null $\mathrm{T}$ head.)

Example (26), above, showed that the weak nominative enclitic cannot be linearly separated from a second position tense particle. The pair in (28) shows that the weak nominative enclitic cannot be linearly separated from a predicate-final tense suffix, either.

(28) Weak nominative enclitics will follow the predicate-final tense suffixes

$\begin{array}{llll}\text { a. Mõket } & \text { nẽ } & \text { e'ẽkapbi'a } & \text { 'en? } \\ \text { mõket } & =\text { nẽ } & \text { e-'ẽk-a-pbi'a } & =\text { ='en } \\ \text { long.ago } & =\text { YES/NO } & \text { 2sG-dance-TH-DURATIVE } & =\mathbf{2 s G}\end{array}$

'Did you used to dance, long ago?'

conversation: 2018-08-22

b. *Mõket nẽ 'en e'ẽkapbi'a?

mõket $=$ nẽ $\quad=$ 'en e-'ẽk-a-pbi'a

long.ago $=$ YES $/ \mathrm{NO}=2 \mathrm{SG}$ 2SG-dance-TH-DURATIVE

(intended to mean the the same as $28 \mathrm{a}$ )

elicitation: 2018-08-23 
There is only one morphosyntactic configuration where the weak nominative enclitic can be linearly separated from tense morphology: when both $(a)$ a tense-marked VP occurs in clauseinitial position and $(b)$ a clause-typing particle is present.

(29) A clause-typing particle will separate the tense suffix from the weak nominative enclitic
a. E'ẽkapbi'a
nẽ
e-'êk-a-pbi'a
$=\mathbf{n} \tilde{\mathbf{e}}$
'en
mõket?
2 SG-dance-TH-DURATIVE
$=\mathrm{YES} / \mathrm{NO}$
='en
mõket
'Did you used to dance?'
=2sG long.ago
elicitation: 2018-08-23
b. Korakora 'epsi mằknan
korakora 'epsi mã̀ k-nẽ-a-n
chicken money send-EVID.SG-TH-NEAR.PAST =UNFORTUNATELY.NOT =1sG
Adão yope.
Adãõ yope
Adam with
'I didn't even send money for the chicken along with Adam (NON-WITNESSED).' conversation: 2018-08-23

These facts are discussed at greater length in the next subsection.

The close relationship between the weak nominative enclitics and tense morphology is illustrated by a small set of portmanteaux. The shape of the polite future particle varies according to the person and number of the subject: $=k o$ is used with the first person singular and first person plural exclusive and $=k e$ is used with the second and third persons, regardless of number. Yet special portmanteaux appear when the subject is first person dual inclusive or first person plural inclusive.

(30) Portmanteaux with polite future and first person inclusive subjects
a. Patõampe kit ikap.
patõã-mpe =kit i-ko-ap
roast-after SAME.SUBJECT $_{\text {POLITE.FUTURE }+1 \text { DUAL.INCL }}$ 3-eat-ADV.FOC
'Let us-INCL.DUAL eat it after roasting it.' / 'We-INCL.DUAL ought to
eat it after roasting it.'
text: Paulina Tomika Tupari, narrator

b. Kiema'erẽ

kitwat

ki-ema'ẽ-re

$=$ kitwat

1PL.INCL-language-OBL

$=$ POLITE.FUTURE + 1PL.INCL

kiapsitwàromkap.

ki-apsitwat-ro-'om-ka-ap

1PL.INCL-forget-NMZ-NEG-VBZ-ADV.FOC

'Let us-INCL not forget our language.' / 'We-INCL ought not to forget our language.' text: Nilson Tupari, narrator 
Given that the first person inclusive enclitics are otherwise 'okit and 'okitwat, we would expect ${ }^{*} k o$ 'okit in (30a) and *ko 'okitwat in (30b); but the only possible forms are kit and kitwat, respectively. This conflation of tense together with person and number features of the subject suggests analyzing the weak nominative enclitics as a kind of agreement on $\mathrm{T}$ rather than as true pronominal arguments, contra Alves (2004).

The weak nominative enclitics highlighted in (25) through (30) are not optional: they cannot be removed without rendering the utterances ungrammatical. But whereas these enclitics are obligatory with the predicate-final tense suffixes and with the second position tense particles, they are prohibited from cooccuring with the auxiliaries that provide present, future, and sameday past interpretations (see Singerman 2018b, ch. four for paradigms and examples). Hence utterances like the following four never include weak nominative enclitics.

Auxiliary constructions that never combine with weak nominative enclitics
a. Herem
tarape ĩrẽ
opop'a
o'apteka.
herem
tarape ${ }^{\tilde{1}-\mathrm{re}}$
o-pop'e-a
o-'apteka
since.then stingray-OBL 1SG-fear-TH
'Since then I have been afraid of stingrays.'

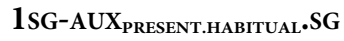
(never occurs with the weak nominative enclitic ='on '1SG')
text: Rita Sisi Tupari, narrator

b. Sebola tàn kit kot'oa nã otea.

sebola tàn kit kot'oy-a nã ote-a

onion tall seed want-TH PROG 1PL.EXCL-AUX.PL

'We-EXCL are wanting onion seeds.'

(never occurs with the weak nominative enclitic ='ote '1PL.EXCL')

conversation: 2016-02-09
c. Suk'am kiarapkap'a kia.
suk'am ki-arop-ko-a-p'a ki-a
later 1PL.INCL-food-eat-TH-NEAR.FUTURE 1PL.INCL-AUX.PL
'We are going to eat our food later.'
(never occurs with enclitic ='okit '1PAUC.INCL' or ='okitwat '1PL.INCL')
conversation: 2014-06-30

d. Yonyonke nã watwakaro pewarap.

yonyonke nã wat-waka-ro pewarap

whistling FOCUS 2PL-cry-NMZ DISTANT.FUTURE+2PL

'You-PL will cry by whistling.'

(never occurs with the weak nominative enclitic =wat '2PL')

text: Miraci Aguissi Tupari, narrator

The absence of the weak nominative enclitics in these utterances is due to the fact that the right sort of tense morphology is missing. That is, these utterances lack a predicate-final tense suffix or second position tense particle, on which the weak nominative enclitics are parasitic.

To summarize, the weak nominative enclitics $(a)$ may only occur with a specific subset of tense morphology (the predicate-final suffixes and second position particles, but not the post-VP 
auxiliaries); (b) must follow the tense morphology in the linear string; and (c) in at least one case are realized via portmanteaux with tense. All of these factors suggest that these morphemes are not actual pronouns, as claimed in prior descriptive work on Tuparí, but instead instantiate agreement between the subject and the $\mathrm{T}$ head. If ='on ' $1 \mathrm{SG}^{\prime}$, ='en ' $2 \mathrm{sG}$ ', and the other weak nominative enclitics were true subjects it would be difficult to make sense of their restriction to a particular subset of $\mathrm{T}$ heads. If, however, these enclitics are some kind of agreement morphology, their circumscribed distribution is less worrisome. Recent work on the agreement/ argument distinction exploits this same logic: Nevins (2011) and Kramer (2014) argue that insensitivity to T/INFL is diagnostic of argument clitics rather than agreement morphology. In that Tuparí weak nominative enclitics are parasitic on certain kinds of tense marking, we have good reason to analyze them as agreement rather than true arguments.

\subsection{Concerning the surface position of the weak nominative enclitics}

Section 5 argued that the second position tense particles and the predicate-final tense suffixes arrive in their surface positions via postsyntactic dislocation operations: Head Raising and Head Lowering, respectively. If the morphemes referred to here as weak nominative enclitics are the realization of agreement between the T head and the subject, we must ask what mechanism is or mechanisms are - responsible for ensuring that the weak nominative enclitics always follow the tense morphology in the linear string.

I assume here that the weak nominative enclitics reflect the application of the standard Agree mechanism utilized in much Minimalist research (Chomsky 1995). The T head will have unvalued features for person and number; these features are valued via the application of Agree between $\mathrm{T}$ and the subject, which is base-generated in Spec,VP. Once the Tense head's features for person and number are valued by Agree, they can be realized as the appropriate member from the set of enclitics in Table 1. In the case of the polite future portmanteaux (examples 30a and 30b), specific spell-out rules will fuse the tense particle and the weak nominative enclitic into a single form, one incapable of further morphological segmentation. In all other cases, the weak nominative enclitic will be spelled out as separate from, but directly attached to, the tense morpheme. If the weak nominative enclitic and $\mathrm{T}$ together form a single complex head, they will be capable of undergoing the dislocation operations of Head Raising (which places the particles $=k o / k e$ 'POLITE.FUTURE', $=\tilde{o}$ pot 'DISTANT.PAST' and $=k u$ ' 'ANCIENT.PAST' in second position) and Head Lowering (which attaches the suffixes $-t / n$ 'NEAR.PAST' and -pbi'a/mbi'a 'DURATIVE' to the right edge of the predicate). Since the weak nominative enclitic will move with the tense morphology as it undergoes Head Raising / Head Lowering, it will always remain adjacent to tense.

Although I have referred to these morphemes as enclitics, they could plausibly be treated as suffixes - suffixes that are subcategorized to attach directly on top of tense morphology. (As will be discussed further in Section 6.4, below, comparative evidence indicates that the Tuparí weak nominative enclitics are partway through a grammaticalization process from independent pronoun to enclitic pronoun to agreement affix.) There is only one phenomenon that mitigates against treating the weak nominative enclitics as synchronic suffixes: they may be linearly separated from a tense suffix by an intervening clause-typing particle. This was shown in (29) for both the near past and durative suffixes. In no other circumstance may the weak nominative enclitic be separated linearly from a tense suffix; what is more, I know of no circumstance where 
a weak nominative enclitic may be linearly separated from a second position tense particle. Were it not for examples such as (29), then, there would be no evidence against an analysis of the weak nominative enclitics as agreement suffixes glued directly onto the $\mathrm{T}$ head. I therefore propose that utterances such as (29a) and (29b) be treated as the product of a special adjustment rule, one that applies late in the derivation and takes as its input the linear order of the morphemes. ${ }^{13}$

$$
\begin{array}{ll}
\text { Proposed linear adjustment rule } \\
\text { input: } & \text { Tense suffix - weak nominative enclitic - clause-typing particle } \\
\text { output: } & \text { Tense suffix - clause-typing particle - weak nominative enclitic }
\end{array}
$$

The input for this rule makes reference to a hypothesized intermediate step where the clausetyping particle follows rather than precedes the weak nominative enclitic. Such an intermediate step would be derived straightforwardly given the other operations already argued for. In particular, Agree will lead to the valuation of the person and number features on the $\mathrm{T}$ head, giving rise to the weak nominative enclitic as an enclitic or suffix that immediately follows the tense morphology. Subsequently, the operation of Head Lowering will bring the complex head consisting of $\mathrm{T}$ and the weak nominative enclitic down onto the lexical verb. Finally, the VP will front to Spec,CP, just as in (23), carrying the tense suffix and weak nominative enclitic along. This set of operations yields the input for the adjustment rule in (32). And since that set includes both narrowly syntactic and postsyntactic operations, the adjustment rule proposed here must apply very late in the derivation. This is in keeping with the general approach toward linearitysensitive operations in the Distributed Morphology framework (see, for instance, Arregi and Nevins 2012): they must follow operations that refer to hierarchical syntactic structure.

\subsection{Comparing the weak nominative enclitics against the strong pronouns}

The weak nominative enclitics are partially homophonous with a separate set of strong pronouns; these strong pronouns are free from the rigid restrictions that circumscribe the distribution of the weak nominative enclitics. This partial homophony helps to explain why the two classes of morphemes were not differentiated in earlier descriptive work.

Table 2. The set of strong pronouns

\begin{tabular}{|l|c|c|}
\hline & SINGULAR & PLURAL \\
\hline 1 1INCL & \multirow{2}{*|}{ on } & kit \\
\cline { 1 - 2 } $1 \mathrm{EXCL}$ & & ote \\
\hline 2 & en & wat \\
\hline 3 & \multicolumn{2}{|c|}{ hè and other demonstratives } \\
\hline
\end{tabular}

\footnotetext{
${ }^{13}$ Thank you to David Pesetsky for first suggesting this analytic route to me.
} 
There is much morphosyntactic evidence that the strong pronouns, which are listed in Table 2, qualify as true nominals. For instance, they can bear the same range of case morphology attested on non-pronominal NPs. (33) illustrates with the instrumental case, which takes the shape $-o$ after consonants and $-m$ after vowels.

Strong pronouns can bear case morphology

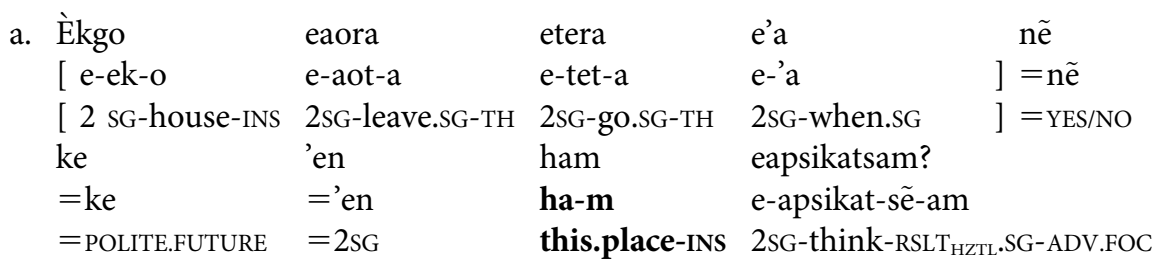

'When you arrive at your home, are you going to keep thinking of this place?' conversation: 2016-02-17

b. Otem ke 'en eapsikara e'eka.

ote-m =ke ='en e-apsikat-a e-'eka

1PL.EXCL-INS = POLITE.FUTURE $=2 \mathrm{SG}$ 2SG-think-TH 2sG-AUX $\mathrm{HABTT}_{\mathrm{H}} \mathrm{SG}$

'Please be thinking of us- EXCL.'

conversation: 2018-09-01

c. Wapsikara 'on ẽrõ, ma'ã 'en herõwap hem.

w-apsikat-a ='on en-o [ $\varnothing$-ma'ẽ-a ='en herõwap ] he-m

1SG-think-TH $=1 \mathrm{SG}$ 2sG-INS [ 3-speak-TH $=2 \mathrm{SG}$ yesterday ] NMZ-INS

'I thought about you, about the thing that you said yesterday.'

conversation: $2017-08-14$

In (33a) the instrumental-marked nominal root is ha 'this place, here', yielding ham 'to this place, hither'. In (33b) the instrumental case attaches to the strong pronoun ote '1PL.EXCL'. And in (33c) the instrumental case surfaces twice, once on the strong pronoun $\tilde{e} r \tilde{\boldsymbol{o}}$ and once on the nominalizer hem. The latter morpheme subordinates the finite embedded clause ma'a 'en herõwap hem 'about the thing that you said yesterday', which functions as an internally-headed relative. (See Section 4.2 for more examples of clausal nominalizations headed by hè he.) That non-pronominal NPs and strong pronouns will bear the same case morphology in the same syntactic contexts strongly suggests that the strong pronouns are true nominals.

The strong pronouns can also take the plural-like collective suffix -'eat, widely attested on non-pronominal NPs: Tupari 'Tuparí' $\rightarrow$ Tupari'eat 'the Tuparí people, the many Tuparí; onõ 'my friend(s), my relative(s)' $\rightarrow$ onõ'eat 'my many friends / relatives'. The ability of the strong pronouns to bear collective -'eat is shown by (34).

\begin{tabular}{|c|c|c|c|c|}
\hline $\begin{array}{l}\text { Kisie } \\
\text { ki-si }\end{array}$ & 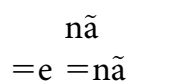 & $\begin{array}{l}\text { teapsikarat } \\
\text { te-apsikat-a-t }\end{array}$ & $\begin{array}{l}\text { kiro } \\
\text { kit-o }\end{array}$ & $\begin{array}{l}\text { / kit'earo. } \\
\text { / kit-'eat-o }\end{array}$ \\
\hline 1 PL.INCL-mother & $=3=$ FOCUS & 3C-think-TH-NUC & 1PL.INCL-INS & / 1 PL.INCL-many-INS \\
\hline
\end{tabular}


In contrast, speakers reject putting -'eat 'many' on the weak nominative enclitics.

Recall that the weak nominative enclitics never occur with present progressive, present habitual, or future auxiliaries (example 31, in Section 6.1). In contrast, the strong pronouns are allowed in any and all contexts.

(35) illustrates with second person forms. The strong pronouns in these three examples mark a change in topic and bear the nuclear case suffix.

Strong pronouns allowed in all contexts, even ones that ban weak nominative enclitics

$\begin{array}{lllll}\text { a. Katke } & \text { nã } & \text { eyẽ } & \text { ẽren? } \\ \text { katke } & \text { nã } & \text { e-yẽ } & \text { en-en } \\ \text { how } & \text { PROG } & \text { 2sG-AUX } \text { HZTL }_{\text {SG }} & \text { 2sG-NUC }\end{array}$

'As for you, how are you doing?'

conversation: 2016-07-08

b. Here ẽren ke ewakto pe'ap...

here en-en ke e-wak-to pe'ap

and 2sG-NUC like.this 2sG-cry-NMZ DISTANT.FUTURE+2SG

'And as for you, you will cry like this...'

text: Miraci Aguissi Tupari, narrator

c. Kat'aro mãkẽrõ nã wat'oro'e waret.

kat'aro =mãkẽrõ nã wat-oro'e wat-et

how.many = DONT.KNOW PROG 2PL-AUX ${ }_{\mathrm{GO}}$.PAUC 2PL-NUC

'As for you-PL, I don't know how many of you-PL there are.' conversation: 2016-12-14

The present and future auxiliaries in (35) are not compatible with the weak nominative enclitics, which require that tense be realized either as a second position particle or as a predicate-final suffix. Yet the nuclear-marked strong pronouns can and do occur here. This fact supports analyzing the strong pronouns as true arguments but weak nominative enclitics as agreement on $\mathrm{T}$. Since the strong pronouns are not dependent on the T node the way that the weak nominative enclitics are, they may combine with the full range of tense marking.

Indeed, nuclear-marked strong pronouns can cooccur with weak nominative enclitics as long as the right kind of tense morphology is present. In (36a) and (36b), that morphology is the second position particle $=k e$ 'POLITE.FUTURE'.

(36) Strong pronouns and weak nominative enclitics can cooccur

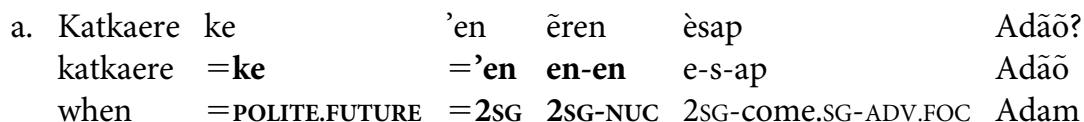

'And as for you, Adam, when will you come back here?'

conversation: $2017-03-26$ 


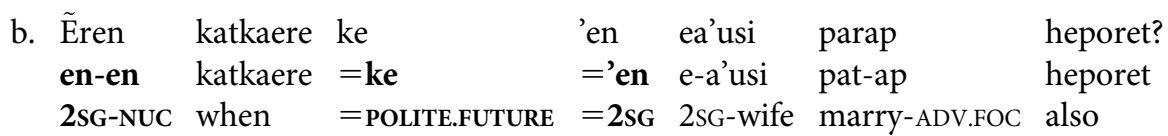

'And as for you, when will you take a wife, too?' conversation: 2016-07-26

The position of the weak nominative enclitic ='en '2SG' is fixed: it must immediately follow the second position tense particle $=k e$ ' $2 \mathrm{sG}$ ', which itself follows the clause-initial $w h$-word katkaere 'when'. But the position of the strong pronoun êren ' $2 \mathrm{sG}+\mathrm{NUC}$ ' is much more flexible. It may follow the second position cluster, as in (36a), or it may occur in a high, extrasentential position, as in (36b). In the latter case a prosodic break separates the extrasentential strong pronoun and the clause-initial wh-word, which sits in Spec,CP.

\subsection{Summary and comparative discussion}

The Tuparí language possesses two distinct sets of morphemes that were conflated in prior scholarship. Although the strong pronouns are partially homophonous with the weak nominative enclitics, the latter morphemes are parasitic on the second position particles and predicate-final suffixes, which they must linearly follow. They cannot, however, cooccur with the post-verbal auxiliaries that mark the same-day past, present and future. Whereas these auxiliaries paradigmatically contrast with the second position tense particles and the predicate-final tense suffixes, the weak nominative enclitics are highly restricted in their distribution. They are 'just' agreement, not true arguments.

Before turning to superficially tenseless clauses, in Section 7, we should address a marked difference between Tuparí and its best-described sister language, Sakurabiát (referred to in some prior literature as Mekens). According to Galucio (2014) (see also Galucio 2001, 38-43), subject pronouns are required in Sakurabiát only with transitive verbs. The following paradigm from Galucio (2014, 378; my highlighting) illustrates.

(37) Subject pronouns are optional with intransitive verbs in Sakurabiát
a. e-et-a-t
(ẽt) $\quad$ eni $=$ ese
2 SG-sleep-TH-PAST (you) hammock $=$ LOC
'You slept in the hammock.'
b. o-et-a-t
(õt)
1 SG-sleep-TH-PAST
'I slept.'
c. o-so-a-t ẽt
1sG-see-TH-PAST you
'You saw me.'
d. e-so-a-t õt
2 SG-See-TH-PAST I
'I saw you.'


Sakurabiát does not require overt subject pronouns with intransitive verbs such as et 'sleep' but does require them with transitive verbs such as $s o(p)$ 'see'. This pattern makes intuitive sense given the Tuparían languages' pattern of absolutive marking on lexical verbs. Intransitive verbs in the Tuparían languages always bear a pronominal prefix that conveys the person and number features of the subject. Hence the bolded pronouns in (37a) and (37b) are informationally redundant: they provide the same person-and-number information transmitted by the verb's pronominal prefix. However, as transitive verbs in the Tuparían languages take an object prefix, the bolded pronouns are required in (37c) and (37d): without those pronouns, there would be no information in these utterances about the person and number of the subject. For this reason the pronouns which are optional in (37a) and (37b) must be included in (37c) and (37d).

But Tuparí crucially differs from the Sakurabiát paradigm given in (37). In Tuparí, the presence of a weak nominative enclitic is conditioned entirely by the kind of tense marking employed, without regard to the valence of the lexical verb. Hence ='en ' $2 \mathrm{sG}$ ' is obligatory after the second position tense particle $=k e$ 'POLITE.FUTURE' both in (38a), where the verb is intransitive 'come.SG', and in (38b), where the verb is transitive 'give.' Thanks to the absolutive argument marking pattern found on lexical verbs throughout the Tuparian family, the intransitive verb 'come.SG' in (38a) carries a pronominal prefix; and that prefix provides the same person-and-number information that the weak nominative enclitic does. Nonetheless, the weak nominative enclitic cannot be omitted.

The weak nominative enclitic ='en ' $2 \mathrm{SG}$ ' is not optional, even with intransitive verbs

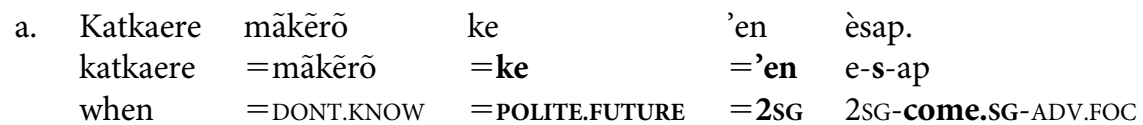

'I don't know when you're going to come here.'

conversation: $2016-10-05$

b. Katkaere mãkẽrõ ke 'en warop õam.

katkaere =mãkẽrõ =ke ='en w-arop om-ap

when = DONT.KNOW = POLITE.FUTURE $=2 \mathrm{sG}$ 1SG-thing give-ADV.FOC

'I don't know when you're going to give me my thing / my gift.'

conversation: 2016-11-10

As this minimal pair demonstrates, the valency of the lexical verb has no impact whatsoever on whether a weak nominative enclitic will be present. Rather, the distribution of the weak nominative enclitics is determined by the realization of $\mathrm{T}-\mathrm{a}$ functional category which sits much higher than the VP in the clausal spine and which is therefore independent of the lexical verb's argument structure.

It is interesting to note that three subject pronouns - the first person singular, second person singular, and first person plural exclusive - may optionally encliticize onto the verb phrase in Sakurabiát (Galucio 2001, 41-43). This gives rise to alternations between SOV and OVS word order: the former order arises when the subject pronouns are clause-initial and the latter, when they have encliticized onto the VP. Similar variation between SOV and OVS is reported for another member of the Tuparían branch of the Tupían family, Wayoro (Nogueira 2011, 72-74; 
see also Nogueira 2019, ch. two). Tuparí appears to have undergone a more extreme version of the same encliticization process documented for Sakurabiát and Wayoro, with formerly independent pronouns now fully reanalyzed as Tense-parasitic agreement.

\section{TENSE MORPHOLOGY IN SUPERFICIALLY TENSELESS CLAUSES}

The previous section used the dependence of the weak nominative enclitics on a particular subset of tense marking to argue that these enclitics do not qualify as subject pronouns but instead constitute agreement between the subject and the $\mathrm{T}$ head. This section inverts that logic: it uses the presence of weak nominative enclitics in superficially tenseless environments to establish the existence of two different phonologically null tense morphemes. The null $\mathrm{T}$ head that combines with verbal predicates behaves morphosyntactically like the second position particles $=k o / k e$ 'POLITE.FUTURE', $=\tilde{o}$ pot 'DISTANT.PAST' and $=k u t$ 'ANCIENT.PAST', while the null T head that combines with nominal predicates behaves morphosyntactically like the predicatefinal suffixes $-t / n$ 'NEAR.PAST' and -pbi'a/mbi'a 'DURATIVE'.

\subsection{Null tense marking with verbal predicates}

Verbal predicates that do not combine with overt tense marking receive one of two temporal interpretations, depending on their lexical semantics. A eventive/telic verb such as $k o$ 'eat, drink' receives an immediately-prior-to-UT interpretation, while a stative/non-telic verb such as otetka 'exceed, be taller than' receives a present one. ${ }^{14}$ The near-minimal pair in (39) illustrates for the former case. In (39a), the clause-initial constituent is the verb phrase weut'eutkia and the instrumental-marked NPs arom and 'iporo occur after the weak nominative enclitic ='on. In (39b), it is the instrumental-marked NP which occurs clause-initially; the VP (bearing the adverbial focus suffix $-a p$ ) follows the weak nominative enclitic.

(39) Weak nominative enclitic shows up in second position in superficially tenseless clauses

Weut'eutkia 'on arom, 'iporo.
w-eut'eutki-a ='on $\operatorname{aro(p)-m}$ 'ipot-o
1sG-fill.up-TH =1sG food-INS fish-INS
'I have filled up on food, on fish [just now].'
conversation: $2016-11-21$

b. Takam'ã suram 'on weut'eutkiap.

takam'ã sura(p)-m ='on w-eut'eutki-ap

agouti cooked-INS =1sG 1sG-fill.up-ADV.FOC

I have filled up on cooked agouti [just now].

conversation: 2016-11-21

\footnotetext{
${ }^{14}$ The resultative suffix -psẽe/pnẽ/psira can transform eventive/telic verbs into stative/non-telic ones. Hence epsik 'sit down' is interpreted as immediate past when used in a finite clause that lacks overt tense marking, but epsiksẽe 'be in the state of having sat down, remain sitting' receives a present interpretation in the same environment (Singerman 2019). For the ease of presentation this subsection focuses on telic predicates only.
} 
The weak nominative enclitic ='on ' $1 \mathrm{sG}$ ' surfaces in second position in both of these utterances; the syntactic category of the clause-initial constituent does not affect the enclitic's placement. As examples like (39a) and (39b) receive a consistent temporal interpretation, they are justifiably analyzed as containing a null tense morpheme that contributes that interpretation. And as the weak nominative enclitic in these examples occurs in second position, that null tense morpheme must sit in second position as well. (40) provides revised glosses for (39).

(40) Revised glosses, with null IMMEDIATE.PAST particle in second position

$\begin{array}{lllll}\text { a. Weut'eutkia } & \text { 'on } & \text { arom, } & \text { 'iporo. } \\ \text { w-eut'eutki-a } & \varnothing & =\text { 'on } & \text { aro(p)-m } & \text { 'ipot-o } \\ \text { 1 SG-fill.up-TH } & =\text { IMMEDIATE.PAST } & =1 \text { 1sG } & \text { food-INS } & \text { fish-INS } \\ \text { 'I have filled up on food, on fish [just now].' } & & \end{array}$
b. Takam'ã suram 'on weut'eutkiap.
takam'ã $\operatorname{sura}(\mathrm{p})-\mathrm{m}=\varnothing \quad=$ 'on w-eut'eutki-ap
agouti cooked-INS = IMMEDIATE.PAST $=1$ sG 1 sG-fill.up-ADV.FOC
'I have filled up on cooked agouti [just now].'

The following near-minimal triple illustrates further. In each of these utterances the clauseinitial constituent is a non-finite adverbial clause headed by -ro'are 'while', the weak nominative enclitic occurs in second position, and the main verb comes at the end of the clause and bears -ap/am 'ADV.FOC'. Example (41c) must contain a null tense particle akin to overt $=\tilde{o}$ pot 'DISTANT.PAST' in (41a) and overt $=k o$ 'POLITE.FUTURE' in (41b). This null particle ensures $(a)$ that the weak nominative enclitic ='on ' $1 \mathrm{sG}$ ' will surface in second position and $(b)$ that the utterance receives the correct temporal interpretation.

(41) Near-minimal triple with $=\varnothing$ 'IMMEDIATE.PAST' in second position
a. Cidadzire
otet'ero'are
opore
hare
[ cidadzi-re
o-tet'e-ro'are
] $=\tilde{\text { oppot }}$
$=\mathbf{e}$ hare
[ city-OBL
$1 \mathrm{SG}-\mathrm{AUX}_{\mathrm{GO}} \cdot \mathrm{SG}$-while ]=DISTANT.PAST $=\mathbf{3}$ here
irik'enemnam.
irik'e-nẽ-mnẽ-am
work-VBZ-EVID.SG-ADV.FOC
'While I was in the city, she worked here (NON-WITNESSED).'
conversation: 2016-02-06
b. Nika etet'ero'are ko 'on watoa
[ $\varnothing$-nîk-a e-tet'e-ro'are ] =ko ='on w-ato-a
[ 3-write-TH $2 \mathrm{SG}$-AUX ${ }_{\mathrm{GO}} \mathrm{SG}$-while ] = POLITE.FUTURE $=$ 1sG 1sG-bathe-TH
owãram.
o-wan-am

1sG-go.nearby-ADV.FOC

'While you are writing it down, let me go a short distance to bathe.'

conversation: 2018-01-22 


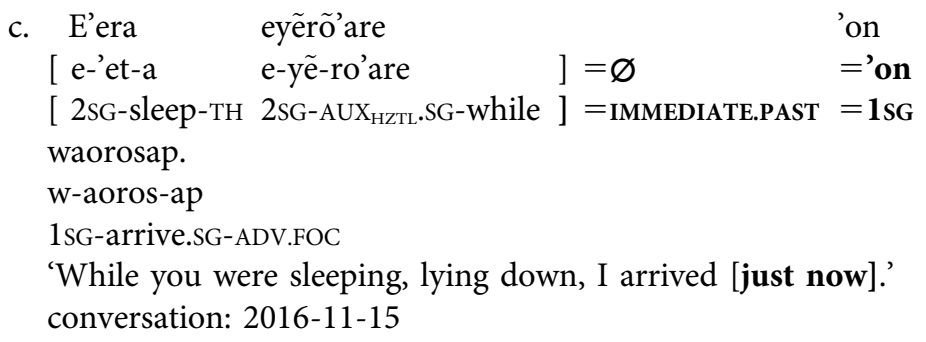

The appendix addresses an alternate placement pattern for weak nominative enclitics in verbal clauses with no overt tense marking.

\subsection{Null tense marking with nominal predicates}

Nominal predicates also cooccur with weak nominative enclitics (42) illustrates. In each of these utterances, a nominal predicate (soka 'cold', kisot'asap 'our dying', puop 'knowledgeable, smart') occurs with a weak nominative enclitic despite the absence of any overt tense morphology.

(42) Examples of weak nominative enclitics with nominal predicates

$\begin{array}{llll}\text { a. Het'aem nẽ } & \text { sokae? } & \\ \text { het'aem } & \text { nẽ } & \text { soka } & =\mathbf{e} \\ \text { where.you.are }=\text { YES/NO cold } & =\mathbf{3} \\ \text { 'Is it cold where you are?' } & & \\ \text { conversation: } 2016-04-02 & \end{array}$

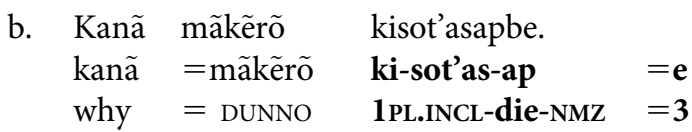

'I don't know why we have to die.' [lit. 'I don't know why there is our dying.'] conversation: 2017-08-16
c. Arikapu ema'ẽre nẽ 'en?
Arikapu ema'ẽ-re =nẽ puop ='en
Arikapu language-OBL $=$ YES/NO knowledgable $=2 \mathrm{sG}$
'Do you know the language of the Arikapu?'
conversation: 2016-07-09

Given that the weak nominative enclitics are otherwise known to be dependent on a subset of tense marking, it must be the case that clauses like these contain more functional material than meets the eye. In other words, these clauses must contain a null $\mathrm{T}$ head.

Yet unlike the $=\varnothing$ 'IMMEDIATE.PAST' proposed in Section 7.1, the null tense morpheme in (42a) through (43) cannot sit in second position. This is because the weak nominative enclitics in clauses with nominal predicates do not appear in second position; rather, they always follow the nominal predicate itself. This fact is clear from (42a) through (42c): in each of these three utterances a clause-typing particle follows the clause-initial constituent whereas the weak 
nominative enclitic follows the nominal predicate. Only when the nominal predicate is itself the clause-initial constituent will the weak nominative enclitic occur in second position. This is shown by (43), where puop 'knowledgeable, smart' is clause-initial. Examples such as this one are structurally parallel to (29), from Section 6, where the clause-typing particle linearly separates the predicate-final tense suffix from the weak nominative enclitic.

$$
\begin{aligned}
& \text { Puop nẽ 'en espanhol ema'em èma'aerẽ? } \\
& \text { puop =nẽ ='en espanhol ema'ẽ-m e-e-ma'ẽ-am-ere } \\
& \text { knowledgeable }=\text { YES/NO }=2 \mathrm{sg} \text { Spanish language-INS 2SG-INTRANS-speak-NMZ-OBL } \\
& \text { 'Do you know how to speak in the Spanish language?' }
\end{aligned}
$$$$
\text { conversation: 2017-02-09 }
$$

In sum, even though nominal predicates and superficially tenseless verbal predicates resemble one another in lacking overt tense morphology, they differ markedly in terms of the placement of the weak nominative enclitics.

To make sense of the placement of the weak nominative enclitics with nominal predicates we must take another look at the predicate-final suffixes $-t / n$ 'NEAR.PAST' and $-p b i$ 'a/mbi'a 'DURATIVE'. Consider the following two pairs of examples, which build upon the generalizations discussed in Sections 6.1 and 6.2. In (44a) and (45a), the clause-typing particle $=n \tilde{e}$ 'YES/NO' follows the clause-initial constituent and the weak nominative enclitic ='en occurs immediately after the tense-marked VP. In (44b) and (45b), the tense-marked VP occurs as the clause-initial constituent and the weak nominative enclitic follows the clause-typing particle. That is, the enclitic $=$ 'en '2SG' will cliticize directly onto the predicate as long as no clause-typing particle intervenes.

(44) Weak nominative enclitics are sensitive to the position of the near past suffix

$\begin{array}{llll}\text { a. Haytokia } & \text { ne } & \text { epuop'orat } & \text { 'en? } \\ \text { haytokia } & =\text { nẽ } & \text { e-puop'ot-a-t } & =\text { 'en } \\ \text { a.lot } & =\text { YES/NO } & \text { 2sG-learn-TH-NEAR.PAST } & =2 \text { sG }\end{array}$

'Did you learn a lot?'

conversation: 2018-08-31

b. Epuop'orat nẽ 'en haytokia?

e-puop'ot-a-t =nẽ ='en haytokia

2SG-learn-TH-NEAR.PAST $=$ YES/NO $=2 \mathrm{SG}$ a.lot

'Did you learn a lot?'

elicitation: 2018-09-01

(45) Weak nominative enclitics are sensitive to the position of the durative suffix

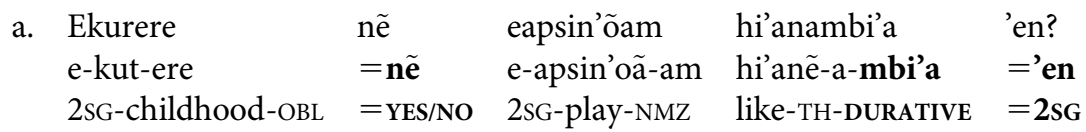

'Did you like to play in your childhood?'

conversation: 2016-02-10 


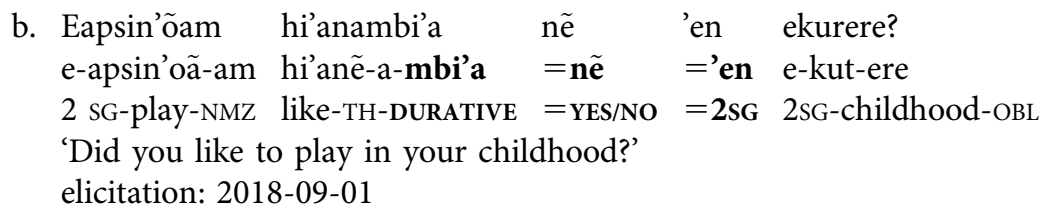

In terms of the placement of the weak nominative enclitics, clauses with nominal predicates (examples 42 and 43) behave just like clauses with verbal predicates where $\mathrm{T}$ is realized as a predicate-final suffix (examples 44 and 45). Given these parallels, the kind of null $\mathrm{T}$ head that is present in clauses with nominal predicates must be akin to the predicate-final suffixes $-t / n$ 'NEAR.PAST' and -pbi'a/mbi'a 'DURATIVE' rather than to the second position particles $=k o / k e$ 'POLITE.FUTURE', $=\tilde{o}$ pot 'DISTANT.PAST', or $=k u t$ 'ANCIENT.PAST'. That is, this null T head must undergo postsyntactic Lowering to attach to the right edge of the predicate. This mechanism ensures that the weak nominative enclitic - independently known to depend parasitically on $\mathrm{T}$ - will follow the nominal predicate in the linear string.

(46) provides revised glosses for (42a) through (42b) and for (43), with the null tense suffix and the weak nominative enclitic now highlighted.

(46) Revised glosses, with the null PRESENT/PAST suffix attached to the nominal predicate
a. Het'aem
nẽ
sokae?
het'aem
$=$ nẽ
soka- $\varnothing$
where.you.are
$=\mathrm{YES} / \mathrm{NO}$
cold-PRESENT/PAST
$=\mathbf{e}$

'Is it cold where you are?'

b. Kanã mãkẽrõ kisot'asapbe.

kanã $=$ mãkẽrõ ki-sot'as-ap- $\varnothing \quad=\mathbf{e}$

why $\quad=$ DUNNO 1PL.INCL-die-NMZ-PRESENT/PAST $=3$

'I don't know why we have to die.' [lit. 'I don't know why there is our dying.']

c. Arikapu ema'ẽre nẽ 'en?

Arikapu ema'ẽ-re =nẽ puop- $\varnothing \quad=$ en

Arikapu language-OBL $=$ YES/NO knowledgable-PRESENT/PAST $=\mathbf{2 S G}$

'Do you know the language of the Arikapu?'

d. Puop nẽ 'en espanhol ema'em

puop- $\varnothing \quad=$ nẽ $\quad=$ 'en espanhol ema'ẽ-m

knowledgeable-PRESENT/PAST $=$ YES/NO $=2 \mathrm{sG}$ Spanish language-INS

èma'aerẽ?

e-e-ma'ẽ-am-ere

2sG-INTRANS-speak-NMZ-OBL

'Do you know how to speak in the Spanish language?' 


\subsection{Enclitic placement in negated clauses confirms the existence of a null tense suffix on nominal predicates}

The suffix -'om, which serves as both a negator (NEG) and a privative (PRIV), maps nouns to nouns; negated constituents in Tuparí behave nominally rather than verbally according to a slew of morphosyntactic diagnostics (Singerman 2018a). If the generalizations given in the previous subsection about the placement of the weak nominative enclitics are accurate - and if negated predicates are just a kind of nominal predicate - then we predict that negated predicates should behave identically to all other nominal predicates as far as the nominative enclitics' placement is concerned.

This prediction is correct. (47) illustrates. The weak nominative enclitics behave alike with negated predicates built from nominalized verbs (examples $47 \mathrm{a}$ and $47 \mathrm{~b}$ ) and with predicates where -'om attaches directly to a noun (47c and $47 \mathrm{~d})$.

Negated predicates behave like nominal predicates with regards to enclitic placement

$\begin{array}{llll}\text { a. Wekgere } & \text { nẽ } & \text { èmo'ãkto'om } & \text { 'en? } \\ \text { w-ek-ere } & =\text { nẽ } & \text { e-emo'ãk-to-'om- } \varnothing & =\text { 'en } \\ \text { 1sG-house-OBL } & =\text { YES/NO } & \text { 2sG-pass.by-NMZ-NEG-PRESENT/PAST } & =2 \text { sG }\end{array}$

'Did you not pass by my house?'

conversation: 2016-02-19

b. Adãõ iypek noro'om 'en?

Adãõ iy-pek ko-ro-'om- $\varnothing \quad=$ nẽ ='en

Adam OBJ.NMZ-buy eat-NMZ-NEG-PRESENT/PAST $=$ YES/NO $=\mathbf{2 S G}$

'Did you not eat what Adam bought?'

conversation: 2015-10-20

c. Kiema'erẽ nẽ puop'ommẽ?

ki-ema'ẽ-re $=$ nẽ puop-'om- $\varnothing=\mathbf{e}$

1PL.INCL-language-OBL =YES/NO knowledgeable-NEG-PRESENT/PAST $=\mathbf{3}$

'Is he not knowledgeable of our-INCL language?'

conversation: 2017-06-21

d. Koy'om nẽ 'en?

koy-'om- $\varnothing \quad=$ nẽ $\quad=$ 'en

sister-PRIV-PRESENT/PAST $=$ YES/NO $=\mathbf{2}$ SG

'Do you not have a sister?'

conversation: 2016-02-15

Observe that in (47a) and (47c) the negated predicate occurs after the second position clause-typing particle $=n \tilde{e}$ 'YES/NO', whereas in (47b) and $(47 \mathrm{~d})$ it occurs clause-initially immediately prior to the clause-typing particle. As a result, the clause-typing particle linearly separates the weak nominative enclitic from the negated predicate in (47b) and (47d).

In terms of the placement of the weak nominative enclitics, these examples with -'om 'NEG/PRIV' pattern identically to the non-negated nominal predicates in (46). This fact not 
only reinforces the nominal nature of negation in Tuparí (Singerman 2018a) but also provides evidence for the existence of the null tense suffix argued for in the previous subsection.

\subsection{Summary}

The data examined in this section have shown that a null $\mathrm{T}$ head is present even in superficially tenseless clauses. Yet as the position of the weak nominative enclitics differs depending on the category of the predicate (nominal or verbal), the language must possess two distinct null $\mathrm{T}$ heads. We thus arrive at the following lists of tense morphemes that will cooccur with the weak nominative enclitics:

(48) Tense particles that undergo Head Raising from $\mathrm{T}$ to $\mathrm{C}$ so as to arrive in second position

a. $=k o / k e$ 'POLITE.FUTURE' (plus the portmanteaux forms given in example 30)

b. $\quad=\tilde{o}$ pot 'DISTANT.PAST'

c. $=k u t$ 'ANCIENT.PAST'

d. $=\varnothing$ 'IMMEDIATE.PAST' (restricted to verbal predicates)

(49) Tense suffixes that undergo Head Lowering from $\mathrm{T}$ so as to attach to the predicate

a. $-t / n$ 'NEAR.PAST'

b. - pb'ia/mbi'a 'DURATIVE'

c. $-\varnothing$ 'PRESENT/PAST' (restricted to nominal predicates)

The only tense morphology that does not combine with the weak nominative enclitics are postverbal auxiliaries of the kind shown in (31) and (35) (discussed at greater length in Singerman 2018b, ch. four). Although these auxiliaries function paradigmatically as members of the language's set of tense morphology, they never appear alongside the weak nominative enclitics and are thus excluded from the lists in (48) and (49).

\section{CONCLUSION}

This article has described the relative positions of several functional categories in the Tuparí clause, with a special focus on the distribution of head-initial and head-final phrase structure. We have seen that, as in many other Tupían languages, the lower region of the Tupari clause obeys rigid head-final structure. However, the highest layer - instantiated by the second position clause-typing particles - is head-initial. The Tense Phrase, sandwiched in between the CP and the Evidential Phrase, shows a surface split in headedness: the suffixes $-t / n$ 'NEAR.PAST' and - $p b i$ ' $a$ / mbi'a 'DURATIVE' are predicate-final (just like evidential -pnẽ /psira), whereas the particles $=k o / k e$ 'POLITE.FUTURE', = o pot 'DISTANT.PAST' and $=k u t$ 'ANCIENT.PAST' must always surface in second position (just like the clause-typing particles). We have argued that this surface split is a reflection of indeterminate underlying headedness in the TP.

With these facts in place it became possible to investigate the weak nominative enclitics and to contrast them against the strong pronouns; the two sets of morphemes were improperly conflated 
in previous scholarship on the language. The distribution of the weak nominative enclitics supports an analysis on which these morphemes are agreement between the subject and $\mathrm{T}$ rather than true arguments of the predicate. Furthermore, the appearance of the weak nominative enclitics in clauses that superficially lack tense morphology - and their rigid positioning therein has led to the proposal that Tuparí must have at least two kinds of null $\mathrm{T}$ heads. The null $\mathrm{T}$ head that combines with verbal predicates arrives in second position via the postsyntactic operation of Head Raising, just as the overt particles $=k o / k e,=\tilde{o} p o t$ and $=k u t$ do. And the null $\mathrm{T}$ head that combines with nominal predicates undergoes the postsyntactic Lowering operation to attach to the right edge of the predicate, just as the overt suffixes $-t / n$ and $-p b i a / m b i a$ do.

There are at least two broader contributions that, we hope, this article can make. First, it offers one of the more detailed descriptions and analyses of clausal organization yet provided for a Tupían language outside of the family's Tupi-Guaraní branch. This description and analysis forms part of a broader documentary initiative that is set to include a reference grammar and multilingual text collection. In that much prior scholarship on Tuparí was diachroniccomparative, focused on the language's position within the broader Tupían family, extensive synchronic description has been sorely lacking. Here we have tried to demonstrate that the language's morphosyntactic complexity is worthy of attention in its own right, apart from diachronic-comparative considerations. That being said, many of the synchronic phenomena described and analyzed in this article raise questions that ought to be addressed in future comparative work. For example, how does the graded tense system found in Tuparí compare to the tense systems described for its sister languages? Can the diachronic development of this system be mapped out? And as mentioned in Section 6.4, the grammaticalization process that transformed erstwhile freestanding pronouns into T-parasitic agreement morphology in Tuparí may also be in progress in at least two other members of the Tuparían branch of the Tupían family, Sakurabiát and Wayoro. What I have argued here for Tuparí (i.e., that nominative enclitics are synchronically wholly distinct from true pronouns) may apply more broadly in Tupían.

Second, we hope that this article can contribute to the broader typology of syntactic headedness. As briefly discussed in Section 5.3, the structure of Tuparí matrix clauses conforms to the predictions of the Final-over-Final Condition (see Holmberg 2000; Biberauer et al. 2014; Sheehan et al. 2017; Hein and Murphy 2020, among others). FOFC bans configurations of the form ${ }^{*}\left[{ }_{\alpha \mathrm{P}}\left[{ }_{\beta \mathrm{P}} \beta \gamma \mathrm{P}\right] \alpha\right]$ where $\alpha$ and $\beta$ share the same category feature; that is, a head-final $\alpha \mathrm{P}$ cannot dominate a head-initial $\beta \mathrm{P}$ within a single Extended Projection. The organization of Tuparí matrix clauses obeys FOFC: head-initiality is instantiated at the highest levels of the clause while the clause's lowest region is head-final. And in between these two zones of clear headedness we find the indeterminate TP. However, the finite clauses nominalized by hè are capable of violating the strictest form of FOFC, as discussed in greater detail in Singerman (2020). The Tuparí facts described and analyzed here thus have the potential to inform the typological foundation of FOFC, whose status as a hardwired property of the Language Faculty or as a statistical tendency influenced by processing considerations is still a matter of debate.

\section{Appendix: An alternative placement pattern for the weak nominative enclitics}

Section 7.1 showed weak nominative enclitics surface in second position in superficially tenseless verbal clauses; this pattern points toward the existence of a phonologically null second position 
tense particle akin to the overt polite future, distant past and ancient past particles. However, for some speakers the weak nominative enclitic can follow the predicate-final affix -ap/am 'ADV.FOC'. (50a) shows the placement pattern from Section 7.1, while (50b) shows the alternative:

Alternative placement of weak nominative enclitics

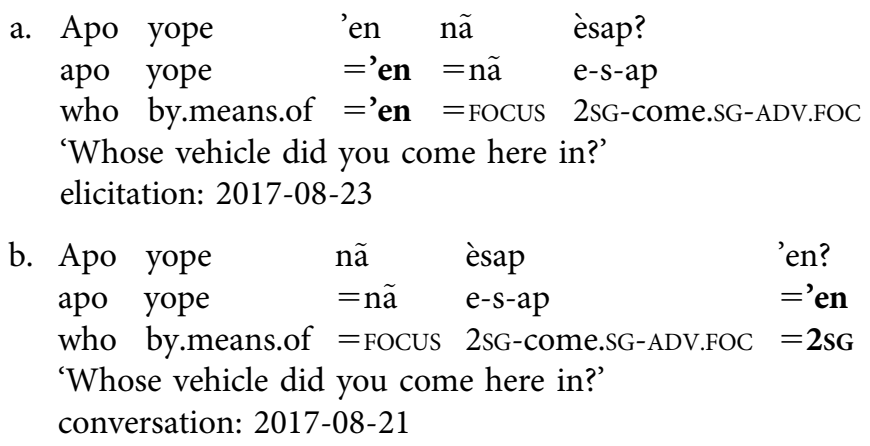

One way of analyzing this alternation is to say that the null IMMEDIATE.PAST morpheme may, for at least some speakers, pattern either like a second position tense particle or like a predicate-final suffix. If (50b) contains a null tense suffix after -ap/am 'ADV.FOC', then the weak nominative enclitic placement would follow straightforwardly. (It is unlikely that -ap/am 'ADV.FOC' has been reanalyzed in these circumstances as a realization of $\mathrm{T}$, since it combines freely with the full range of second position tense particles. That is, if the adverbial focus suffix did belong to the set of tense morphemes, then the paradigmatic opposition and mutual exclusivity of those morphemes would be undermined.)

Consultants approve the alternation in (50) readily, and it is attested in everyday spontaneous discourse as well. Nonetheless, it is my distinct impression that (50b) - with the weak nominative enclitic positioned after the adverbial focus-marked predicate - is less common than (50a), where it occurs in second position. The alternative in (50b) also appears to be more common in the speech of younger and middle-aged Tuparí; I have never heard it used by an elderly member of the community. More research into this alternation is needed, especially in that the pattern in (50b) does not seem to occur in the absence of the suffix -ap 'ADV.FOC' on the lexical verb. See Singerman (2018b, 163-166) for more information on the adverbial focus suffix, which is subject to considerable intergenerational and interpersonal variation.

\section{ACKNOWLEDGMENTS}

This paper is a revised version of the fifth chapter of my dissertation (Singerman 2018b). I thank my dissertation committee - Lenore Grenoble, Jason Merchant and Karlos Arregi - as well as audience members at Amazonicas VII, the University of Chicago, WSCLA 24, the Museu Paraense Emílio Goeldi, and the Hungarian Academy of Sciences. For detailed feedback I also thank two anonymous reviewers for the Acta Linguistica Academica as well as editor Éva Dékány. A special thank you goes to several Tupíanist colleagues in Brazil who have provided 
feedback on my description and analysis of Tuparí clause structure over the past several years: Ana Vilacy Galucio, Denny Moore, and Luciana Storto. Any and all errors that may remain are my own responsibility.

Dozens upon dozens of Tuparí speakers contributed to this project. I would like to extend a special thank you to the following speakers for working with me during my summer 2018 trip to Rondônia: Cristiane Tupari, Daiane Arikapu, Eliane Osi’uy Tupari, Elizangela Waiká Tupari, Gabriel Akorai Tupari Paulo Tupari, Pedro Mãykware Tupari, Rita Sisi Tupari, Rodrigo Tupari, Sandro Sawãy Tupari, Tereza Paruká Tupari, and Valmira Pa'urota Tupari. A special thank you also to the political leadership of the Tuparí community on the Rio Branco Reserve and to the indigenous schoolteachers from the Rio Branco, especially Isaias Tarimã Tupari, Raul Pat'awre Tupari, Geovane Kamarom Tupari and Arlene Pairosá Tupari.

For financial support for my fieldwork, I extend my heartfelt gratitude to the Jacobs Research Funds at the Whatcom Museum and to the National Science Foundation's Documenting Endangered Languages Program (award number 1563228). Thank you also to the linguists at the Museu Paraense Emílio Goeldi for providing me with an institutional affiliation in Brazil.

\section{REFERENCES}

Alves, Poliana Maria. 1991. Análise fonológica preliminar da língua Tuparí [Preliminary phonological analysis of the Tuparí language]. Master's thesis, Universidade de Brasília.

Alves, Poliana Maria. 2004. O léxico do Tuparí: proposta de um dicionário bilíngüe [The lexicon of Tuparí: proposal for a bilingual dictionary]. Doctoral Dissertation, Universidade Estadual Paulista, Araraquara.

Anderson, Stephen R. 2005. Aspects of the theory of clitics. Oxford: Oxford University Press.

Aragon, Carolina Coelho. 2014. A grammar of Akuntsú, a Tupian language. Doctoral Dissertation, University of Hawai'i at Mānoa.

Arregi, Karlos and Nevins Andrew. 2012. Morphotactics: Basque auxiliaries and the structure of spellout. Dordrecht: Springer.

Basilico, David. 1996. Head position and internally headed relative clauses. Language 72(3). 498-532.

Bhatt, Rakesh Mohan. 1999. Verb movement and the syntax of Kashmiri. Dordrecht: Kluwer.

Biberauer, Theresa, Holmberg, Anders, and Roberts, Ian. 2014. A syntactic universal and its consequences. Linguistic Inquiry 45(2). 169-225.

Brandon, Frank Roberts and Seki, Lucy. 1981. A note on COMP as a universal. Linguistic Inquiry 12(4). 659-665.

Brandon, Frank Roberts and Ferreira Seki, Lucy. 1984. Moving interrogatives without an initial $+w h$ node in Tupí. In Eung-Do Cook and Donna B. Gerdts (eds.) Syntax and semantics, volume 16: The syntax of Native American languages. Orlando: Academic Press. 77-103.

Caspar, Franz. 1956. Tupari. London: Bell.

Caspar, Franz. 1957. A aculturação da tribo Tuparí [The acculturation of the Tuparí tribe]. Revista de Antropologia 5(2). 145-171.

Caspar, Franz. 1975. Die Tuparí: ein Indianerstamm in Westbrasilien [The Tuparí: an Indian tribe in western Brazil]. Berlin: Walter de Gruyter.

Caspar, Franz and Rodrigues, Aryon Dall'Igna. 1957. Versuch einer Grammatik der Tuparí-Sprache [An essay on the grammar of the Tuparí language]. Unpublished manuscript. 
Caspar, Franz and Rodrigues, Aryon Dall'Igna. 2017. Esboço da gramática da língua Tuparí [Sketch of the grammar of the Tuparí language]. Translated by Enrique Huelva Unterbäumen, Laura Wägerle, Ariel Pheula do Couto e Silva and Ana Suelly Arruda Câmara Cabral. Brasília: Laboratório de Línguas e Literaturas Indígenas, Universidade de Brasília.

Chomsky, Noam. 1995. The minimalist program. Cambridge, Massachusetts: MIT Press.

Cole, Peter. 1987. The structure of internally headed relative clauses. Natural Language and Linguistic Theory 5(2). 277-302.

Comrie, Bernard. 1981. Language universals and linguistic typology: syntax and morphology. Chicago: University of Chicago Press.

den Besten, Hans. 1983. On the interaction of root transformations and lexical deletive rules. In Werner Abraham (ed.) On the formal syntax of the Westgermania. Amsterdam: John Benjamins. 47-131.

Dixon, R. M. W. 1979. Ergativity. Language 55(1). 59-138.

Dryer, Matthew S. 1992. The Greenbergian word order correlations. Language 68(1). 81-138.

É Kiss, Katalin. 1998. Identificational focus versus information focus. Language 74(2). 245-273.

Embick, David and Noyer, Rolf. 2001. Movement operations after syntax. Linguistic Inquiry 32(4). 555595.

Gabas Jr., Nilson. 1999. A grammar of Karo, Tupí (Brazil). Doctoral Dissertation, University of California, Santa Barbara.

Galucio, Ana Vilacy. 2001. The morphosyntax of Mekens (Tupi). Doctoral Dissertation, University of Chicago.

Galucio, Ana Vilacy. 2002. Word order and constituent structure in Mekens. Revista da ABRALIN 1. 5174.

Galucio, Ana Vilacy. 2011. Subordinate adverbial constructions in Mekens. In: Rik van Gijn, Katharina Haude, and Pieter Muysken (eds).Subordination in Native South American Languages. Amsterdam: John Benjamins. 25-43.

Galucio, Ana Vilacy. 2014. Argument marking and reference tracking in Mekens. In Rik van Gijn, Jeremy Hammond, Dejan Matić, Saskia van Putten, and Ana Vilacy Galucio (eds) Information structure and reference tracking in complex sentences. Amsterdam: John Benjamins. 373-396.

Galucio, Ana Vilacy and de Souza Nogueira, Antônia Fernanda. 2011. Comparative study of the Tupari branch of the Tupi family: contributions to understanding its historical development and internal classification. Paper presented at the V Congreso de Idiomas Indígenas de Latinoamérica, held at the University of Texas at Austin in October 2011. URL https://ailla.utexas.org/sites/default/files/ documents/Galucio_Nogueira_CILLA_V.pdf.

Grimshaw, Jane. 2000. Locality and extended projection. In Peter Coopmans, Martin B.H. Everaert, and Jane Grimshaw (eds.) Lexical specification and insertion. Amsterdam: John Benjamins. 115-133.

Grimshaw, Jane. 2005. Extended projection. In Words and structure. Stanford: Center for the Study of Language and Information, 1-73.

Haider, Hubert and Martin Prinzhorn (eds.) 1986. Verb Second phenomena in Germanic languages. Dordrecht: Foris Publications.

Halpern, Aaron. 1995. On the placement and morphology of clitics. Stanford: Center for the Study of Language and Information.

Hanink, Emily A. 2020 (online first). DP structure and internally headed relatives in Washo. Natural Language \& Linguistic Theory.

Harizanov, Boris, and Vera Gribanova. 2019. Whither head movement? Natural Language \& Linguistic Theory 37(2). 461-522. 
Harley, Heidi. 2013. Getting morphemes in order: merger, affixation, and head movement. In Lisa Lai-Shen

Cheng and Norbert Corver (eds.) Diagnosing syntax. Oxford: Oxford University Press. 44-74.

Harley, Heidi and Rolf Noyer. 1999. Distributed morphology. Glot International 4(4). 3-9.

Hawkins, John A. 2004. Efficiency and complexity in grammars. Oxford: Oxford University Press.

Hawkins, John A. 2014. Cross-linguistic variation and efficiency. Oxford: Oxford University Press.

Hein, Johannes and Murphy Andrew. 2020 (online first). VP nominalization and the Final-over-Final

Condition. Linguistic Inquiry.

Hiraiwa, Ken. 2017. Internally headed relative clauses. In Martin Everaert and Henk van Riemsdijk (eds.)

The Wiley Blackwell companion to syntax, second edition. Hoboken: Wiley Blackwell. 2038-2069.

Holmberg, Anders. 2000. Deriving OV order in Finnish. In Peter Svenonius (ed.) The derivation of VO and

OV. Amsterdam: John Benjamins. 123-152.

Keine, Stefan and Bhatt Rajesh. 2016. Interpreting verb clusters. Natural Language \& Linguistic Theory 34(4). 1445-1492.

Klein, Wolfgang. 1992. The present perfect puzzle. Language 68(3). 525-552.

Kramer, Ruth. 2014. Clitic doubling or object agreement: the view from Amharic. Natural Language \& Linguistic Theory 32. 593-634.

Manetta, Emily. 2011. Peripheries in Kashmiri and Hindi-Urdu. Amsterdam: John Benjamins.

Manetta, Emily. 2020. Expanding the typology of verb second VPE: the case of Kashmiri. In Sam Wolfe and Rebecca Woods (eds.) Rethinking Verb Second. Oxford: Oxford University Press. 723-744.

Martinović, Martina. 2019. Interleaving syntax and postsyntax: Spellout before syntactic movement. Syntax 22(4). 378-414.

Matushansky, Ora. 2006. Head movement in linguistic theory. Linguistic Inquiry 37(1). 69-109.

McCloskey, James. 2017. Ellipsis, polarity, and the cartography of verb-initial orders in Irish. In Enoch

Aboh, Eric Haeberli, Genoveva Puskás, and Manuela Schönenberger (eds.) Elements of comparative syntax: theory and description. Boston: De Gruyter Mouton. 99-151.

Moore, Denny. 1984. Syntax of the language of the Gavião Indians of Rondônia, Brazil. Doctoral Dissertation, City University of New York.

Nevins, Andrew. 2011. Multiple agree with clitics: Person complementarity vs. omnivorous number.

Natural Language \& Linguistic Theory 29(4). 939-971.

Nogueira, Antônia Fernanda de Souza. 2011. Wayoro ẽmẽto: fonologia segmental e morfossintaxe verbal

[The Wayoro language: segmental phonology and verbal morphosyntax]. Master's thesis, Universidade de São Paulo.

Nogueira, Antônia Fernanda de Souza. 2019. Predicação na língua Wayoro (Tupi): propriedades de finitude

[Predication in the Wayoro language (Tupi): properties of finiteness]. Doctoral Dissertation, Universidade de São Paulo.

Ohara, Kyoko Hirose. 2018. Internally headed relativization and related constructions. In Yoko Hasegawa (ed.) The Cambridge handbook of Japanese Linguistics. Cambridge: Cambridge University Press. 485508.

Rizzi, Luigi. 1996. Residual verb second and the Wh-Criterion. In Adriana Belletti and Luigi Rizzi (eds.) Parameters and functional heads: essays in comparative syntax. Oxford: Oxford University Press. 6390.

Rose, Françoise. 2015. On male and female speech and more: categorical gender indexicality in indigenous South American languages. International Journal of American Linguistics 81(4). 495-537.

Seki, Lucy. 1990. Kamaiurá (Tupí-Guaraní) as an active-stative language. In Doris Payne (ed.) Amazonian linguistics. Studies in lowland South American languages. Austin: University of Texas Press, 367-391. 
Seki, Lucy. 2000a. Estratégias de relativização em Kamaiurá [Relativization strategies in Kamaiurá]. In Hein van der Voort and Simon van de Kerke (eds.) Ensaios sobre lenguas indígenas de las tierras bajas de Sudamérica: contribuciones al 49o Congreso Internacional de Americanistas en Quito 1997. Leiden: Research School of Asian, African, and Amerindian Studies (CNWS), Universiteit Leiden, 309-324.

Seki, Lucy. 2000b. Gramática do Kamaiurá: língua Tupi-Guarani do Alto Xingu [Grammar of Kamaiurá: a Tupi-Guaraní language of the Upper Xingu]. Campinas: Editora da UNICAMP.

Seki, Lucy. 2001. Aspectos morfossintáticos do nome em Tupari [Morphosyntactic aspects of the noun in Tupari]. In Aryon Dall'Igna Rodrigues and Ana Suelly Arruda Câmara Cabral (eds.) Línguas indígenas brasileiras. Fonologia, gramática e história. Atas do I Encontro Internacional do Grupo de Trabalho sobre Línguas Indígenas da ANPOLL, Volume 1. Belém: Editora Universitária, Universidade Federal do Pará, 298-308.

Sheehan, Michelle, Biberauer, Theresa, Holmberg, Anders, and Roberts, Ian (eds.) 2017. The Final-overFinal Condition: A syntactic universal. Cambridge, Massachusetts: MIT Press.

Singerman, Adam Roth. 2016. Nasal harmony and phonotactic well-formedness in Tupari. International Journal of American Linguistics 82(4). 453-485.

Singerman, Adam Roth. 2018a. Negation as an exclusively nominal category. Language 94(2). 432-467.

Singerman, Adam Roth. 2018b. The morphosyntax of Tuparí, a Tupían language of the Brazilian Amazon. Doctoral Dissertation, University of Chicago.

Singerman, Adam Roth. 2019. Non-witnessed evidentiality in Tuparí and its connection to resultative constructions in the perfect aspect. International Journal of American Linguistics 85(3). 401-445.

Singerman, Adam Roth. 2020. On finite embedded clauses in Tuparí: their synchronic structure, diachronic origin, and typological importance. Manuscript, University of Chicago.

Storto, Luciana R. 1999. Aspects of a Karitiana grammar. Doctoral Dissertation, Massachusetts Institute of Technology.

Storto, Luciana R. 2003. Interactions between verb movement and agreement in Karitiana (Tupi stock). Revista Letras 60. 411-433.

Storto, Luciana R. 2014. Constituent order and information structure in Karitiana. In Rik van Gijn, Jeremy Hammond, Dejan Matić, Saskia van Putten, and Ana Vilacy Galucio (eds.) Information structure and reference tracking in complex sentences, Amsterdam: John Benjamins. 163-192.

Storto, Luciana R. 2020. Arguments for and against Verb Second in Karitiana. Manuscript, Universidade de São Paulo.

Travis, Lisa deMena. 1984. Parameters and effects of word order variation. Doctoral Dissertation, Massachusetts Institute of Technology.

Vikner, Sten. 1995. Verb movement and expletive subjects in the Germanic languages. New York: Oxford University Press.

Williamson, Janis. 1987. An indefiniteness restriction for relative clauses in Lakhota. In Eric J. Reuland and Alice G.B. ter Meulen (eds.) The representation of (in)definiteness. Cambridge, Massachusetts: MIT Press. 168-190.

Wolfe, Sam and Woods Rebecca (eds.) 2020. Rethinking Verb Second. Oxford: Oxford University Press.

Zeller, Jochen. 2013. In defence of head movement: evidence from Bantu. In Lisa Lai-Shen Cheng and Norbert Corver (eds.) Diagnosing syntax. Oxford: Oxford University Press. 87-111. 